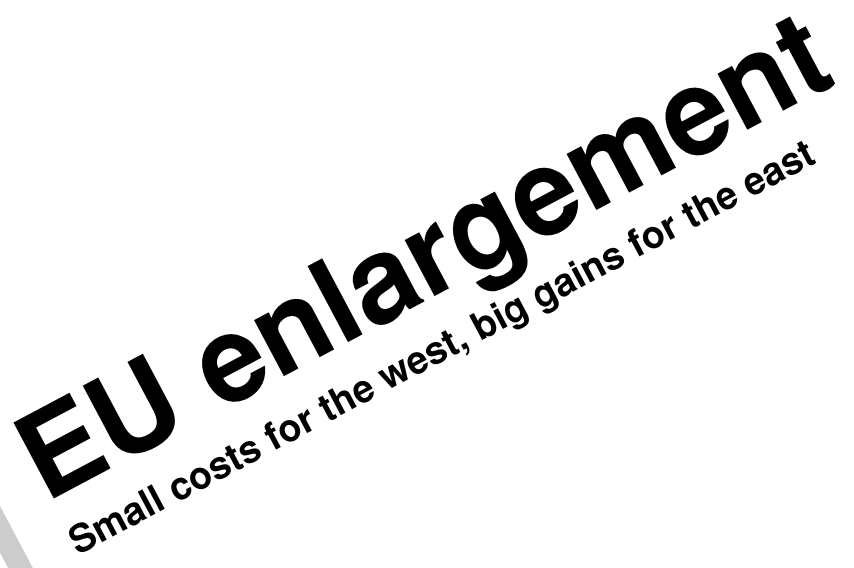

SUMMARY

Eastern enlargement of the EU is a central pillar in Europe's post-Cold War architecture. Keeping the eastern countries out seriously endangers their economic transition, and economic failure in the east could threaten peace and prosperity in western Europe. The perceived economic costs and benefits will dictate the enlargement's timing. There are four parts to the calculus - the costs and the benefits in the east and in the west. Here we break new ground in estimating the economic benefits of enlargement for east and west using simulations in a global applied general equilibrium model. Our analysis includes a scenario in which joining the EU significantly reduces the risk premium on investment in the east - with resulting huge benefits to the new entrants. We also review the existing literature on the EU budget costs and arrive at a surprisingly well-determined 'consensus' estimate, which we support with a new political economy analysis of the budget. The bottom line is unambiguous and strongly positive: enlargement is a very good deal for both the EU incumbents and the new members.

- Richard E. Baldwin, Joseph F. Francois and Richard Portes 



\title{
The costs and benefits of eastern enlargement: the impact on the EU and central Europe
}

\author{
Richard E. Baldwin, Joseph F. Francois and Richard Portes
}

Graduate Institute of International Studies, University of Geneva and CEPR; Erasmus University Rotterdam, WTO and CEPR; London Business School and CEPR

\section{INTRODUCTION}

Just one decade ago, millions of men and trillions of dollars of equipment stood ready for combat in Europe. The demise of the political systems in eastern Europe and the Soviet Union defused the situation. This political 'creative destruction' opened the door to great opportunities, but also to great dangers. On the bright side, a continuing success story in eastern Europe will lock in democracy and promarket reforms. Moreover, a hundred million eastern consumers with rising incomes are a bonanza for western European businesses. Continuing economic success in the east will foster prosperity and peace throughout the continent. On the dark side, however, stagnant or falling incomes and impoverishment of a large slice of the population could foster widespread disillusionment with market economics and democracy. Most worrying of all is that this may occur while a power vacuum exists in central Europe.

Geography and history make these continent-wide problems. Even without speaking of war, any serious unrest or conflict - even if it were limited to the east could harm western Europe via mass migrations, increased defence expenditures 
and changes in investors' attitudes. In short, economic failure in the east could threaten peace and prosperity in western Europe.

There is, fortunately, a simple way simultaneously to ensure the bright-side economic outcome and to alleviate the power vacuum - enlarge the European Union to include the ten central and eastern European countries (CEECs): the Visegrad-5 (Czech Republic, Hungary, Slovak Republic, Slovenia and Poland), the Balkan-2 (Bulgaria and Romania) and the Baltic-3 (Estonia, Latvia and Lithuania). In this sense, eastern enlargement is a central pillar in Europe's post-Cold War architecture. Western European politicians have the power to meet this historic challenge, but contemplation of the economic and financial costs of doing so has led them to procrastinate. In other words, geopolitical considerations constitute the engine driving enlargement, but the economic and financial considerations constitute the brake. This paper looks at the economic costs and benefits of admitting the CEEGs into the EU.

There are four parts to the calculus - the costs and the benefits in the east and the costs and the benefits in the west. Unfortunately, efforts to date have been directed almost exclusively to the costs to the EU budget of an eastern enlargement. Moreover, there is a widely held belief that even this limited debate has been inconclusive. For instance, the Financial Times (16 December 1996) quotes an MEP with a leading role in the enlargement debate, Mr Arie Oostlander, as saying that "the "wildest rumours" were circulating about the cost of enlargement, while the reality was that "adequate reliable information is not currently available". One of the contributions of this article is to argue that a sober evaluation of the literature shows that there is a relatively narrow range of estimates for the budget cost of enlargement. Moreover, this range is quite low compared to the early estimates that stimulated much thinking on the enlargement issue. We believe the estimates below are fairly reliable and indeed adequate for an overall assessment of the economic impact of enlargement.

A second contribution of this article is to fill in two more parts of the calculus: the economic benefits for the east and the west. The final part - the cost of enlargement for the east - seems to defy calculation. The main issue here concerns the extent to which adoption of the European Union's body of legislation and case law - the acquis - will stunt eastern growth and raise unemployment rates. After all, the EU's rules were designed for rich social democracies with extensive social security systems. They are thus unlikely to be appropriate for poorer but rapidly growing eastern nations. Imagine what would have happened if Korea, Taiwan and Hong Kong had been forced to adopt Social Charter rules and EU environmental standards at a comparable stage of their development. The CEECs do need market economy rules, and there is some merit to adopting pre-set rules like the acquis, but the acquis is surely a sub-optimal set of rules for nations in the midst of their 'take-off' stage of growth (see Smith et al., 1995). Quantifying such costs is important, but seemingly impossible. 
The paper is organized in four sections after the introduction. The next section provides an overview of the basic structure of the eastern and western European economies. These facts are essential to understanding our numerical assessment of the economic benefits of eastern enlargement. Section 3 presents a global applied general equilibrium model, which is used to simulate the economic impact of an eastern enlargement. The model produces results for all regions, but we focus on the effects on the CEECs, the EU and the EFTA nations. Section 4 reviews the extensive literature on the EU budget costs of an eastern enlargement and arrives at our 'consensus' estimate of the costs. The final section presents a summary and our concluding remarks.

\section{THE BASIC ECONOMIC FACTS}

\subsection{Relative size: big west and small east}

The current front-runners in the eastern enlargement race are the Czech Republic, Hungary, Poland, Slovenia and the Slovak Republic (although human rights issues threaten to disqualify the latter from the race). Even these front-runners, however, are quite different economically from the EU15, as Table 1 shows. For instance, the EU15 are on average half as agricultural and two and a half times richer than the Visegrad-5. The much lower per capita income in the CEECs reflects (by definition) a much lower labour productivity. A good part of this difference is accounted for by the inferior state of eastern capital stocks and technology. Such factors can be changed rapidly, since installing new machines and adopting new technology are relatively simple, given the high level of education in the GEEGs. Another part depends upon much more intangible factors, such as a well-functioning public administration, respect and knowledge of commercial law and job-specific training of workers. Since these intangibles are in good shape in some CEECs (e.g., the Czech Republic, Slovenia, Estonia, Hungary, Poland and the Slovak Republic), but in bad shape in others, the CEEGs are likely to have very different growth rates in the coming decades. For instance, for the Visegrad-5 and Estonia, the prospects of rapid investment in physical and knowledge capital lead most observers to predict growth rates that are two or three times those of western Europe. This growth gap will narrow income differentials, but it will still take decades before even the richest CEECs catch up to the EU15 average.

Differences between the GEEC and EU populations, multiplied by the incomelevel differences, imply that the two regions are of very unequal economic size. The Visegrad-5 economies taken together, for instance, amount to only about $5 \%$ of the EU15 economy. The relative size is important for a fairly simple reason. International integration boosts incomes by expanding the set of opportunities facing consumers and firms. Typically, this expansion of opportunity enables consumers and firms to arrange their affairs more efficiently, which results in higher output and 
Table 1. Basic economic facts

\begin{tabular}{|c|c|c|c|c|c|}
\hline & \multicolumn{3}{|c|}{1994} & \multicolumn{2}{|c|}{$\begin{array}{c}1993 \\
\text { export shares to: }\end{array}$} \\
\hline & $\begin{array}{l}\text { Population } \\
\qquad(\mathrm{m})\end{array}$ & $\begin{array}{c}\text { Real } \\
\text { per capita } \\
\text { GNP } \\
(\mathrm{US} \$)\end{array}$ & $\begin{array}{c}\text { Agriculture } \\
\text { GDP } \\
\text { share } \\
(\%)\end{array}$ & $\begin{array}{c}\text { CEECs } \\
(\%)\end{array}$ & $\begin{array}{l}\text { EU } \\
(\%)\end{array}$ \\
\hline Czech Republic & 10 & 8990 & 6 & & 63 \\
\hline Hungary & 10 & 6080 & 7 & & 55 \\
\hline Poland & 38 & 5480 & 6 & & 63 \\
\hline Slovak Republic & 5 & 6290 & 7 & & 53 \\
\hline Slovenia & 2 & 6230 & 5 & & n.a. \\
\hline Visegrad-5 & 66 & 6207 & 6 & & \\
\hline Bulgaria & 9 & 4380 & 13 & & 39 \\
\hline Romania & 23 & 4090 & 21 & & 49 \\
\hline GEEC7 & 98 & 5547 & 9 & & \\
\hline Greece & 10 & 10930 & 16 & 13 & 57 \\
\hline Portugal & 10 & 11970 & 4 & 1 & 80 \\
\hline Ireland & 4 & 13550 & 8 & 2 & 72 \\
\hline Spain & 39 & 13740 & 3 & 2 & 73 \\
\hline UK & 58 & 17970 & 2 & 2 & 58 \\
\hline Finland & 5 & 16750 & 5 & 11 & 55 \\
\hline Italy & 57 & 18460 & 3 & 5 & 57 \\
\hline Netherlands & 15 & 18750 & 3 & 3 & 74 \\
\hline Belgium & 10 & 20270 & 2 & 3 & 75 \\
\hline France & 58 & 19670 & 2 & 2 & 64 \\
\hline Austria & 8 & 19560 & 2 & 11 & 65 \\
\hline Germany & 82 & 19480 & 1 & 8 & 57 \\
\hline Sweden & 9 & 17130 & 2 & 3 & 55 \\
\hline Denmark & 5 & 19880 & 4 & 4 & 61 \\
\hline Luxembourg & 0.4 & 35860 & n.a. & n.a. & n.a. \\
\hline EU15 & 369 & 16164 & 3 & 4 & 63 \\
\hline
\end{tabular}

Sources: Population and real GNP/pop. (PPP estimates 1994 Int'l US\$s) World Development Report, 1996, table 1. Agriculture GDP share, World Development Report, 1996, table 12. Trade data from WTO database, using WTO definition of CEECs. Notes: Belgium trade data include Luxembourg. EU trade data for 1994.

income. East-west integration in Europe will plainly expand the CEECs' opportunities much more than it will expand those of the EU, so we should expect the integration to have a larger percentage impact on the GDP of the GEECs, even without undertaking any formal estimates.

\subsection{Trade}

The EU15 sell about $\$ 40$ billion to the CEECs and buy slightly less from them. This trade covers a broad range of goods and consists mainly of two-way trade in similar products, as Figure 1 shows. With the exceptions of 'chemicals and rubber and plastic goods', and capital goods ('transport equipment' and 'other machines and equipment') where the EU is a net exporter, the EU-CEEC trade is approximately 


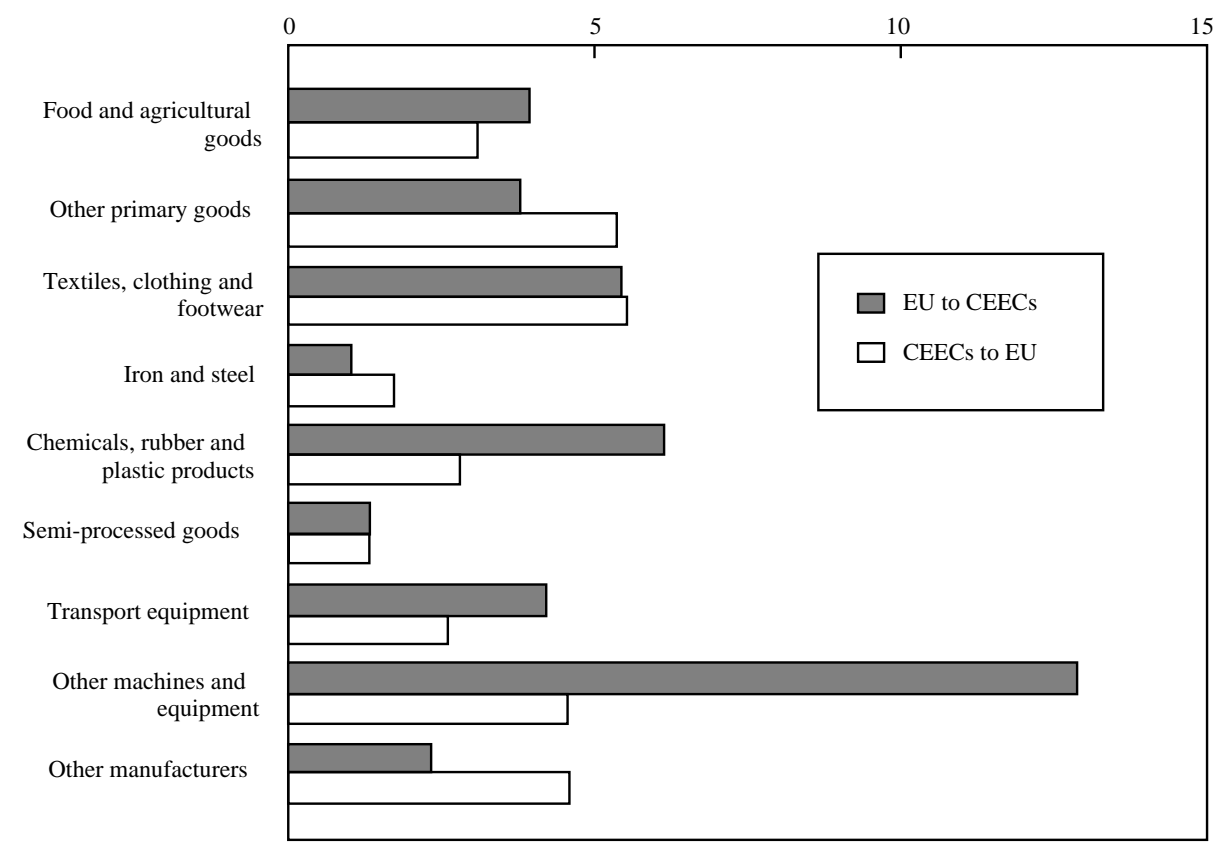

Figure 1. EU-CEEC trade, 1993 (US\$bn)

Source:WTO database.

balanced product by product. With this sort of trade structure, reciprocal liberalization can force sectors to expand in both regions due to improved exploitation of scale economies. At the same time, the relatively unbalanced nature of trade in capital goods points to the potential for significant enlargement-related restructuring in the GEECs that is heavily biased against capital goods.

The EU15's trade with the CEECs is distributed in a very disproportionate manner. Germany alone accounts for $42 \%$ of EU15 exports to the CEEGs, while no other member state accounts for more than $10 \%$ of the EU15 total. Austria, Belgium, Finland, France, Italy, the Netherlands and the UK each account for 5\% or more of the total. At the other extreme, the exports of Portugal and Ireland to the CEECs account for less than $2 \%$ of the EU total.

The last salient point concerns the disparity between the importance of the EU market for CEEC exports and the importance of the CEEC markets for EU exporters. Comparing the last two columns of Table 1, we see that the EU market is critical to CEEC exports, amounting to $50-60 \%$ of all exports (approximately the importance of the EU market for EU nations themselves). However, the CEEG market is fairly unimportant to the EU exporters, with the CEECs taking in about $4 \%$ of EU15 exports (including intra-EU trade). While the welfare gains from trade generally stem from imports rather than exports, national trade policies are typically influenced by mercantilist concerns. It is therefore useful to note that the average EU figure of $4 \%$ hides a good deal of dispersion. For Germany, Austria, Greece and 
Finland the figure is at least double the $4 \%$ average, but for Portugal, Ireland, Spain and the UK, the GEEC markets are only half as important as the EU average.

\subsection{Protection}

The final set of basic facts concerns the level of trade barriers in the CEECs and the EU. Due to the Europe Agreements, the EU has phased out all statutory tariffs on CEEC industrial goods, and the CEECs are in the process of phasing out the same on imports from the EU (Faini and Portes, 1995). Note that duty-free treatment of industrial goods is not really preferential in Europe, since about $80 \%$ of EU imports are accorded such status. In other words, zero statutory tariffs merely level the playing field for Europe's major suppliers. Moreover, zero statutory tariffs do not mean free trade. EU-imposed anti-dumping duties and price-fixing arrangements, meant to avoid such duties, greatly restrict CEEC exports in those areas in which they could expand sales most rapidly - iron and steel in particular. The EU also continues to impose quotas on other so-called sensitive industrial goods, such as textiles, clothing and footwear. CEEC exports of non-industrial goods - especially agricultural goods - have been liberalized only slightly by the EU, and there are no concrete plans to liberalize such trade prior to enlargement.

Figure 2 shows the MFN applied tariff rates for the EU and the CEECs for a range of products. There are three main points to be highlighted. First, the CEEGs are on average more protectionist than the $\mathrm{EU}$, although both are quite open when

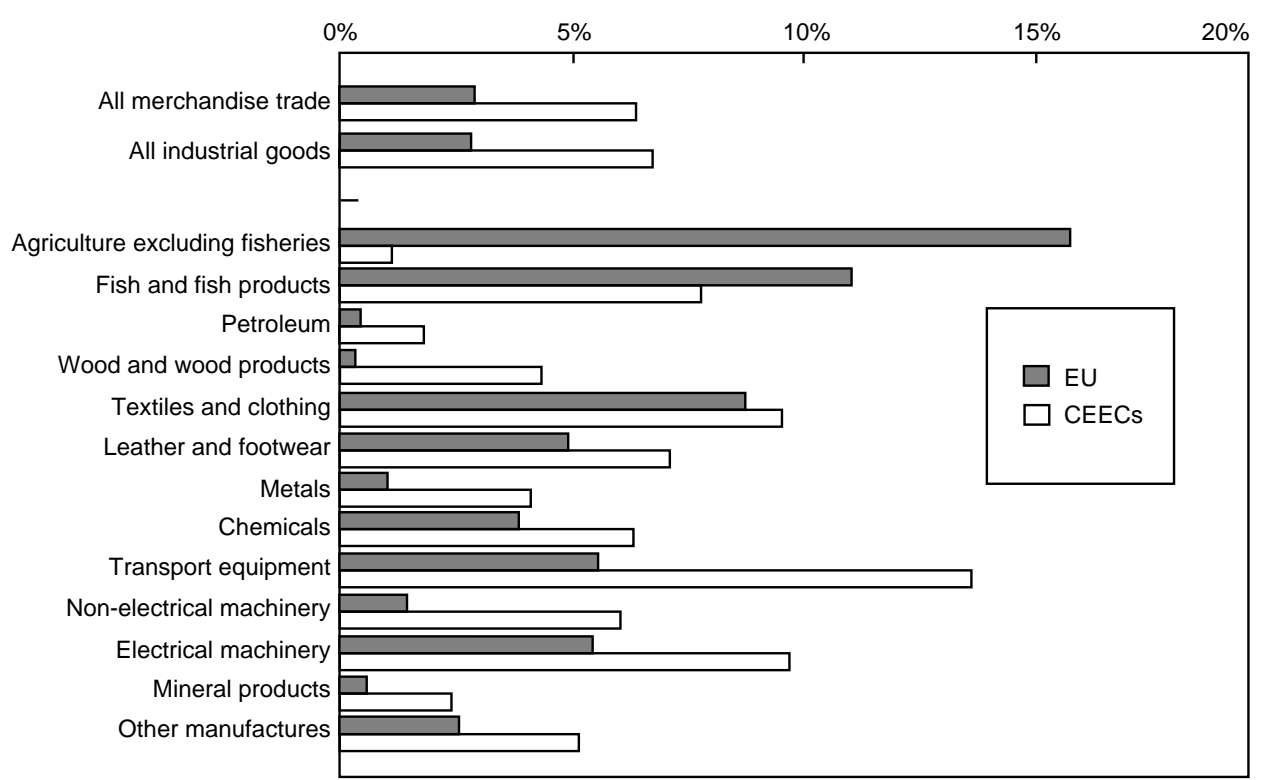

Figure 2. Post-Uruguay Round applied MFN tariff rates

Source: World Bank, Finger et al., 1996. 
compared to developing countries in Asia, Africa and Latin America: the CEECs' average applied tariff is $6.5 \%$, while the EU's is $3 \%$. Second, the CEECs' average of $6.5 \%$ consists of somewhat higher-than-EU rates on industrial goods, but much lower-than-EU rates on agricultural goods. As a result, the enlargement is likely to lead to an important increase in CEEG agricultural protection against third-country suppliers. The same sort of pattern emerged with the Iberian accession, and in that instance third countries, notably the USA, demanded compensation for the hikes in farm protection. The last point is that the gap between the CEEC and EU rates varies widely among industrial goods. For instance, the gap is more than $10 \%$ in transport equipment, but less than $2 \%$ in textiles and clothing, petroleum and mineral products.

This asymmetry of protection rates has important implications for the welfare effects of enlargement. Since two-thirds of CEEC imports are from the EU, and this trade will become free, the ongoing process of joining the $\mathrm{EU}$ implies a great deal of tariff cutting in the CEECs, but very little tariff cutting in the EU (especially since imports from the CEECs amount to only $4 \%$ of EU15 imports). Because most gains come from own-liberalization, the initial levels of protection suggest that enlargement will lead to much greater income gains in the CEECs than in the EU. At the same time, like the pattern of trade, the pattern of protection also suggests that negative restructuring in the CEECs will probably be concentrated in heavy industry.

\section{MEASURING THE ECONOMIC BENEFITS}

The preferential integration of two regions can produce a vast array of economic effects. No longer is it enough to think about 'trade creation' and 'trade diversion': the last ten years have seen important theoretical advances in this area. ${ }^{1}$ Since our results depend heavily on effects that may not be familiar to non-specialists, section 3.1 provides intuition for the new effects and their relationship with older, more standard effects. Section 3.2 briefly presents how we capture all of the various effects of eastern enlargement on the CEEC and EU economies. Section 3.3 discusses the policy experiments and results for the EU as a whole when we make conservative assumptions. Section 3.4 makes less conservative assumptions, while the final section presents some rough calculations on how the gains will be distributed among the incumbent EU15.

\subsection{A primer on the theory of preferential trade liberalization}

A useful classification divides all effects into allocation or accumulation effects (an alternative, but misleading, dichotomy is static and dynamic effects). Allocation

\footnotetext{
${ }^{1}$ See Baldwin and Venables (1995) for a survey and synthesis of such effects.
} 
effects capture the way in which integration induces changes in economic efficiency through resource and expenditure reallocation. Even if we ignore imperfect competition and scale economies (as in the earlier trade creation and diversion literature), we take into account three types of allocation effect, one of which was identified in the last ten years.

The first of these perfect-competition effects stems from trade volume changes: when a good's domestic price exceeds its border price (i.e., the price paid to foreign suppliers), increasing imports lowers the cost of consuming goods and thus raises national welfare. This is the traditional trade creation effect. Clearly, contracting imports in such cases produces the opposite result.

The second effect stems from changes in trade prices. When a country is a net importer of a good, a drop in the border price is beneficial (domestic producers lose less than domestic consumers gain), while the opposite holds when the country is a net exporter. This corresponds roughly to trade diversion, but it is really a composite of two effects: supply switching (typically from a supplier outside the preferential trade area (PTA) to a PTA-based supplier) and the induced changes in the applicable border prices. For instance, if imports came from the lowest-cost supplier prior to preferential liberalization, any switching from non-PTA suppliers to PTA suppliers tends to raise the border price that PTA members pay after the arrangement is implemented. Deepening a PTA tends to lower welfare for PTA members when supply switching is accompanied by a rise in applicable border prices.

The novel third effect is interesting, since it shows that 'trade diversion' (at least the supply-switching part) may actually be welfare improving, although understanding this requires a bit of background. The third effect focuses on trade rents: that is, the revenue that may arise from selling across the gap between low border prices and high domestic prices. Textbook import barriers hand the trade rents either to the domestic government (as in the case of tariffs) or to foreigners (as in the case of price-fixing arrangements or voluntary export restraints). Yet textbook trade barriers have to a large extent been eliminated in western Europe: about $80 \%$ of western European imports are duty-free and, even including applied dumping duties, the EU's trade-weighted tariff is only $3 \%$.

European trade is not free, of course, since many 'frictional' barriers drive wedges between domestic and border prices by raising the real cost of trade (unharmonized product standards are the prime example). Such barriers create no trade rents, they just burn up resources. The interesting point is that eliminating frictional barriers even on a preferential basis - unambiguously lowers border prices. Thus we may observe trade diversion (in the sense of supply switching) that raises national welfare by lowering the cost of imports. Consideration of frictional barriers is central to the evaluation of eastern EU enlargement, since the Europe Agreements eliminate most of the textbook import barriers. To put it differently, EU membership will promote the CEEGs from members of a free trade agreement to members of the EU's single market. 
Since Krugman (1979), trade economists have highlighted the importance of imperfect competition and scale economies. In the process, three 'new' allocation effects have been identified: producer profit effects, scale effects and variety effects (see Francois and Roland-Holst (1996) for details). The first is easy. In sectors where the local price exceeds the average cost of production, an expansion of output raises welfare, since the marginal value of extra output (the price) exceeds the extra cost. A fall in production yields the opposite result. This effect is sometimes called the pure profit effect. Scale effects are also quite intuitive. Average cost falls with the scale of production in most industries, where scale may refer to the size of firms or the size of sectors. Because lower average costs mean more output with the same inputs, positive scale effects tend to improve national welfare. Lastly, integration can increase the range of varieties available to consumers in both regions. More choice makes consumers happier, and, on the production side, a broader variety of input choices can boost industrial productivity.

Accumulation effects are quite a different matter. They highlight channels through which trade arrangements can alter the level of national resources - especially capital stocks - rather than merely reallocate the existing stock of resources. By their nature, accumulation effects tend to have a much larger impact on GDP than allocation effects. Allocation effects involve taking resources out of one activity and putting them into another. The benefit of doing this is limited by the degree to which resource efficiencies initially differ across sectors. In the absence of trade barriers (or other distortions), market forces even out initial sectoral resource efficiencies. It is not surprising, therefore, to find that allocation effects typically yield very small gains in countries that start with well-functioning market economies. Since accumulation effects change the stock of resources, they can lead to much larger changes in the amount of goods that can be produced by the same labour force. (See Baldwin and Francois (1996) and Francois and Reinert (1996) for efforts to capture such effects empirically.)

\subsection{The policy experiments and results: modelling eastern enlargement}

Given enough data, one could construct and estimate an econometric model of the world economy that allowed for all the allocation and accumulation effects mentioned above. This would clearly be the best approach, were it feasible. Unfortunately, the current state of data and theory precludes this tack. Instead, we simulate the economic effects of eastern enlargement by postulating a number of key relationships. ${ }^{2}$ As briefly summarized in Table 2, the model covers all world trade

\footnotetext{
${ }^{2}$ Technically, we employ a calibrated general equilibrium model. While the simulation approach has its shortcomings, it is really the only game in town. This conclusion has also been reached in other fields of applied policy analysis. For instance, proposed tax changes are routinely evaluated with calibrated simulation models in the empirical public finance literature.
} 
Table 2. Sectors and regions in the model

\begin{tabular}{ll}
\hline \hline Sectors & Regions \\
\hline Agriculture, forestry, fisheries & CEEC7 \\
Primary mining and fuels & EU15 \\
Processed foods & EFTA3 \\
* Textiles & Former Soviet Union \\
Apparel & North American Free Trade Area \\
* Non-ferrous metals & Asia-Pacific \\
* Iron and steel & North Africa and Middle East \\
$*$ Chemicals, rubber and plastics & Sub-Saharan Africa \\
$*$ Fabricated metal products & Rest of world \\
$*$ Transport equipment & \\
$*$ Other machinery and equipment & \\
Other manufactures & \\
Services & \\
\hline \hline
\end{tabular}

* Scale economies and imperfect competition.

Note: CEEC7 = Czech Republic, Slovakia, Poland, Hungary, Slovenia, Bulgaria and Romania.

and production, and it allows for scale economies, imperfect competition and endogenous capital stocks. Box 1 provides more discussion of the technicalities for specialists. Interested readers are referred to the 50-page technical appendix to Francois et al. (1995) for detailed discussion of the theoretical structure of the model.

\subsection{Conservative estimates}

EU membership for the CEECs will involve a broad gamut of policy changes. The most obvious involve: (1) elimination of tariffs and quantitative restrictions on all EU-CEEG trade, including agriculture trade, and (2) adoption of the EU's common external tariff (which is generally more liberal than the GEECs' current tariffs against non-western European imports). It will also, however, grant 'single market access' to the EU15 markets for CEEC firms, and the same access for EU firms to the CEEC markets. Single market access involves hundreds of very specific rules (not all of which have even been implemented by the incumbent EU members), so it is impossible to describe in full here. The idea, however, is that it establishes the free movement of goods, services, capital and people. The latter two require open capital markets and unfettered migration. The main elements ensuring the first two freedoms are: (1) the mutual recognition of health, safety, industrial and environmental product standards (after adoption of common minimum standards), (2) the adoption of a common competition policy and a common state-aids policy, and (3) removal of frontier controls.

Incorporating the tariff changes in our model is straightforward, with the exception of agricultural trade. Even though there are no tariffs or quotas on internal EU farm trade (mad cows excepted), the common agricultural policy 


\section{Box 1. The simulation model: technical presentation}

Our model divides the world into nine regions each with thirteen sectors (see Table 2 for region and sector names). Consumers' demands for final-good sectors are generated from a representative regional household with Cobb-Douglas preferences over sectoral composites. Each sector consists of differentiated products and consumers' demand for these are generated by CES preferences. In seven of the sectors (marked by asterisks in the table), we allow for scale economies and imperfect competition, along the lines of the standard Dixit-Stiglitz monopolistic competition model (e.g., fixed mark-ups and free entry). The other sectors are perfect-competition, constant-returns sectors but each region's output is assumed to be differentiated (Armington assumption).

The central feature of all computable general equilibrium models is the input-output structure that explicitly links industries in a value added chain from primary goods, over continuously higher stages of intermediate processing, to the final assembling of goods and services for consumption. The link between sectors may be direct, like the input of steel in the production of transport equipment, or indirect, via intermediate use in other sectors. The model implements this input-output structure by assuming that firms use a mixture of factors (labour and capital) and intermediate inputs. Specifically, factors are combined according to a CES function, while intermediates are used in fixed proportions. This has two significant ramifications: (1) the price of intermediates enters firms' cost functions, so price-raising trade barriers directly affect firms' productivity, and (2) firms' demand for each variety of intermediates follow standard CES deriveddemand functions.

With product differentiation in all sectors (differentiation at the firm level in the increasing-returns sectors and at the regional level in the perfect-competition sectors), the model supports two-way trade in all traded sectors. The cost of trade (a combination of trade and transport services) is modelled explicitly. Revenues from non-frictional trade barriers are returned to the representative consumer in each region.

Regional labour supplies are assumed to be fixed, but regional capital stocks are endogenous. Capital, which includes buildings, is produced according to a fixedcoefficient production function from various intermediate inputs, such as transport equipment and other machinery. The global steady-state capital stocks is the level which balances global savings (regional savings rates are fixed) with global depreciation. Regional capital stocks are then determined by a simplified global capital market. That is, the regional stocks move to maintain the base case relative returns across regions.

The model is calibrated to social accounting data from the last revision (August 1996) to the Global Trade Analysis Project (GTAP) version 3 dataset. The GTAP dataset includes information on national and regional input-output structure, bilateral trade flows, final demand patterns and government intervention, and is benchmarked to 1992. Protection data are based on World Bank and WTO data on pre- and post-Uruguay Round protection. We work with the post-Uruguay Round protection data. Formally, this involves first modelling the impact of the Uruguay Round. We then work with the estimated post-Uruguay Round set of social accounting data for the simulation results presented in this paper. 
(CAP) ensures that trade is definitely not free. We capture this by including a very stylized CAP. Subsidy payments to the EU15 farm sectors are assumed to be sufficient to maintain output at pre-enlargement levels. A second, very different difficulty arises in trying to model single market access. The complexity of single market access makes it impossible for us to model it explicitly in a general equilibrium model. The standard solution to this problem is to model single market access crudely as a reduction in the real cost of trade. In our simulations, we quantify this as a $10 \%$ reduction in real costs of all CEEG-EU trade.

Our first set of results - what we call the conservative scenario - considers only the allocation and accumulation effects that the above-mentioned policy changes have on the global economy. These are presented below. Section 3.4 presents a less conservative set of policy experiments, which allow eastern enlargement - and implicitly the failure of eastern enlargement - to change the risk premiums on investment in the CEECis.

Table 3 presents the aggregate real income and trade effects of eastern EU enlargement for the conservative scenario. ${ }^{3}$ Three aspects of the results are worth mentioning. First, all European regions gain from enlargement. This need not have been the case. For instance, one might have guessed that at least the non-EU European countries (EFTA3 and ex-USSR) might have been harmed by the discriminatory aspects of eastern enlargement. Second, while all income effects are positive, the GEECs gain much more than the EU in relative terms. Specifically, the CEECs' $1.5 \%$ rise in real income is seven times larger than the EU gain. Most of the asymmetric gain can be explained by the fact that the CEEC economies were initially more distorted, so EU enlargement involves a greater degree of ownliberalization. For instance, the initial CEEC applied tariff rate is twice that of the EU. Nevertheless, since the EU15 economy is twenty times larger than that of the

Table 3. Real income effects: conservative case

\begin{tabular}{lcc}
\hline \hline & $\begin{array}{c}\text { Real income change } \\
\text { (1992 ECUbn } \\
\text { change from base case) }\end{array}$ & $\begin{array}{c}\text { Real income change } \\
(\% \text { change } \\
\text { from base case) }\end{array}$ \\
\hline CEEC7 & 2.5 & 1.5 \\
EU15 & 9.8 & 0.2 \\
EFTA3 & 0.2 & 0.1 \\
Ex-USSR & 1.1 & 0.3 \\
\hline \hline
\end{tabular}

Notes: This is a comparative steady-state exercise, so real income changes are not equivalent to utility-based welfare changes. Real income is GDP. EFTA3 is Norway, Iceland and the Swiss-Liechtenstein customs union. Source: Authors' calculations.

\footnotetext{
${ }^{3}$ The model produces results for all nine regions, but the impact on the non-European regions is vanishingly small.
} 
CEECs, the ECU gain to the EU is almost four times greater than the gain to the GEEGs. The third point concerns the aggregate export effects. Due to the combined effect of the CEECs' own-liberalization, improved access to the EU market, and the expansion of the CEEC economies due to positive accumulation effects, the CEECs are projected to increase exports by more than $25 \%$. Since enlargement is only a mild liberalization for the incumbent EU members, aggregate EU15 exports rise by only $1.5 \%$.

As far as the impact on the EU is concerned (by far the most sensitive issue, given EU leaders' fears about the economics of enlargement), our results are in line with Brown et al. (1995). Those authors find that a free trade area between the Visegrad countries and the EU would raise EU real income by ECU13.3 billion. Our results are not exactly comparable to the Brown et al. findings, however, since those authors undertake an exercise that differs in two important ways (apart from the obvious fact that they use a different CGE model that is calibrated to a different data set). First, they examine the effects of a free trade area, not a customs union. Consequently, they do not require the CEECs to adopt the EU's common external tariff. This potentially makes an important difference, since the CEECs have much higher tariffs on heavy industry and much lower tariffs on food. As a result, our results incorporate the effects of much more substantial industrial restructuring than do theirs. Second, they consider only the Visegrad countries rather than the CEEC7 as in our exercise. The economic impact they find for the Visegrad countries amounts to about ECU9 billion, which is much larger than our conservative estimates. As we see below, however, the ECU9 billion of Brown et al. is much smaller than the number we find in our 'less conservative' scenario, to which we turn now.

\subsection{Less conservative estimates}

3.4.1. The risk premium effect. The conservative scenario discussed above includes a simple variation on the classical savings mechanism, by which increased returns to regional capital lead to increased levels of regional investment and hence to an increased capital stock. We do not believe, however, that this will be the end of the story. The CEECs are currently a risky place to invest. Fortunes have been made by those who are lucky (or well connected), but fortunes have been lost. The uncertainty stems from microeconomic sources and macroeconomic sources. Since the transitions began, the micro sources have included, inter alia, bank failures, privatization, bankruptcies, unpredictable changes in subsidy, trade and indirect tax policies, and sudden changes in the legal system, industrial standards and regulation, and administrative procedures. In short, these are economies in transition. At least in those CEEGs that seem likely to join the EU soon, the prospect of EU membership has already greatly reduced the riskiness in one very direct way. EU membership gives investors some idea of the direction in which transition is 
heading. Such is not the case for other economies in transition - the examples of Russia and the Ukraine come to mind - that have virtually no prospect of joining the EU.

The macro sources of uncertainty include unanticipated changes in inflation rates, interest rates and exchange rates. In many of the CEECs, these macro sources of instability are linked to the micro sources. One classic link is that attempts to subsidize sunset industries on a large scale lead to large fiscal deficits that are covered by printing money. Also, a large measure of the inflation in these countries stems from initial price shocks that occurred when prices were liberalized and currencies deeply devalued. Finally, given the potential for political instability in Russia and the lack of security guarantees from, for example, NATO, there remains some small uncertainty about the territorial integrity of the CEECs, especially prior to EU membership.

Joining the EU will make the CEECs substantially less risky from the point of view of domestic and foreign investors. On the micro side, EU membership greatly constrains arbitrary trade and indirect tax policy changes. It also locks in welldefined property rights and codifies competition policy and state-aids policy. By securing convertibility, open capital markets and rights of establishment, membership assures investors that they can put in and take out money. Finally, EU membership guarantees that CEEC-produced products have unparalleled access to the EU15 markets (which account for almost 30\% of world income). On the macro side, membership puts the CEECs on a path to eventual monetary union and thus provides a solid hedge against inflation spurts. These two aspects of membership are likely to have a related impact on investor confidence and are likely to be mutually reinforcing.

3.4.2. Guesstimating the impact on the GEEC risk premium. The statement that EU membership will make the CEECs less risky sites for physical investments seems uncontroversial to us. The hard and therefore controversial part is to quantify the impact that enlargement will have on CEEG risk premiums. Rates of return on capital differ sharply across nations, and these differences are often very persistent. One common explanation for this is that investors demand a risk premium on funds invested in nations with economic and/or political environments that are perceived as unstable.

As Figure 3 shows, country risk does correlate with rates of return. The figure plots, on the horizontal axis, World Bank estimates of the basis point spread charged to emerging economies for dollar-denominated fixed rate issues in 1994. The vertical axis plots country risk indexes for 1995. (A similar pattern, not shown, holds for the spread on the effective dollar yield of domestic debt issues calculated from IMF International Financial Statistics data for medium-term domestic debt issues adjusted for currency movements.) The Czech Republic, Poland and Hungary are arrayed along the middle of the spectrum, with the Czech Republic ranked as the 


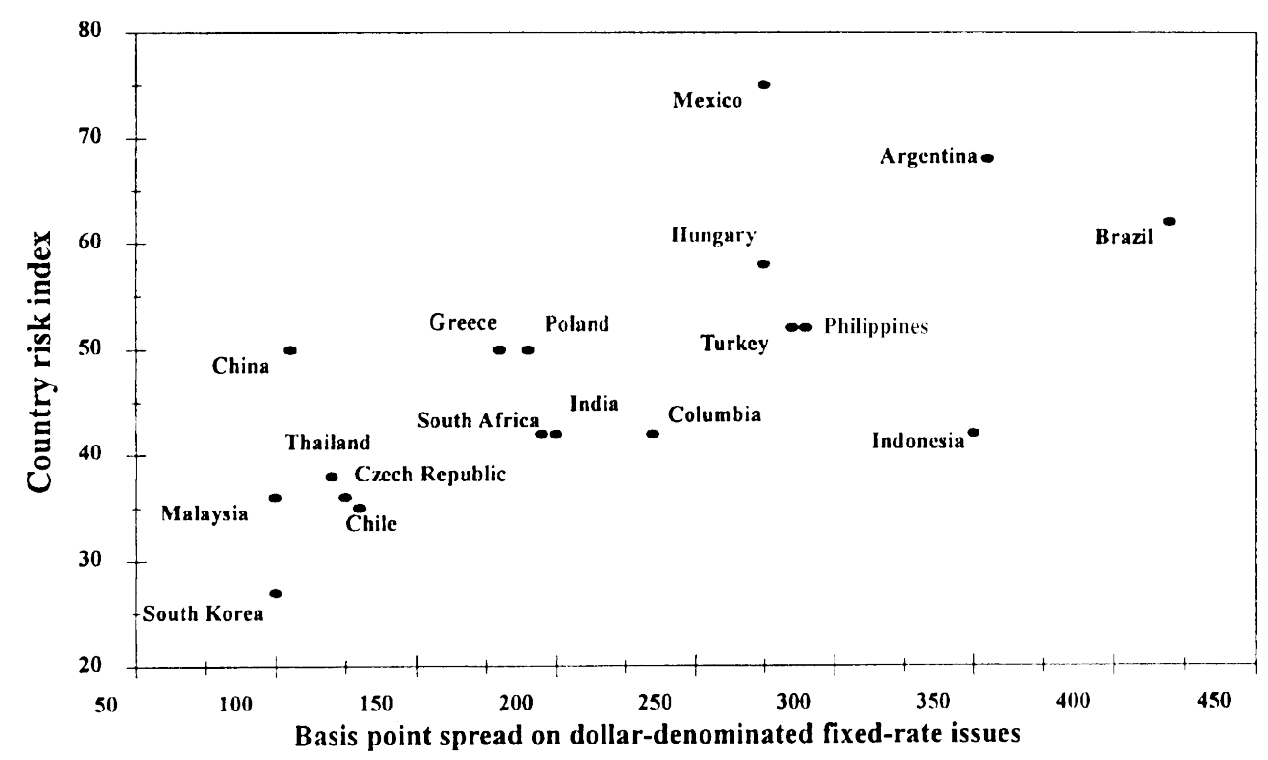

Figure 3. Risk and return in emerging markets

Sources: Horizontal axis risk premium: World Bank estimates from 1996 World Debt Tables, Extracts. Vertical axis country risk index: Economist Intelligence Unit, various issues.

best risk and Hungary as the worst. Poland is ranked as a risk comparable to Greece. Russia is off the charts on both axes, and data for Bulgaria and Romania are unavailable (not a good omen). The unweighted CEEG average for those in the sample (not shown) is located quite close to Poland.

This pattern suggests a simple, albeit rudimentary, way of quantifying the impact of risk on national capital markets. We make the somewhat ad hoc assumption that the GEEC average country risk index moves down to the range of Portugal after EU accession. This implies that the relative return demanded by savers for investment in the region should drop by roughly $15 \%$, which translates to about 45 basis points. Finally, we retain the same trade barrier changes as in the conservative scenario and we assume that the relative regional rates of return are the same for all regions except the CEEGs (which are lowered by 45 basis points). Of course, the CEEG capital stock must rise substantially to bring CEEG capital's actual rate of return down to the new assumed steady-state level.

This approach is plainly quite $a d h o c$, but we feel that it captures an element in the EU membership that is essential for the CEECs. Moreover, there is some historical evidence suggesting a correlation between investment and membership, at least in poor entrants. First, we note that a range of case studies for the Iberian countries also support our basic contention that EU membership can be good for investment in poor entrants. For Spain, the boost to investment from accession and the effect on the current account are documented by Viñals et al. (1990) and by Ortega et al. (1990). The stimulus to foreign investment is analysed by Bajo and Sosvilla (1990). 
For both Portugal and Spain, Braga de Macedo and Torres (1990) specifically demonstrate the decline in country risk premium following accession.

3.4.3. Prima facie historical case. In addition to the detailed case studies listed above, we can make a prima facie case by eyeballing historical data for the six countries that joined the EU during the 1973, 1981 and 1986 enlargements (the 1995 enlargement is too recent to permit study). However, to interpret the historical evidence correctly requires a little theory. A country's capital stock is fixed by the equality of the demand for capital and the supply of capital. Anything that shifts either schedule will change the equilibrium (i.e., steady-state) capital stock. If the change requires the nation's capital stock to rise, above-normal investment will result. The opposite is predicted for changes that require the nation's capital stock to drop.

The theoretical situation is shown in Figure 4, where the solid lines indicate the initial situation. The demand curve shows that the marginal product of capital declines when the capital stock rises, due to economy-wide diminishing returns. The capital supply curve shows that savers will demand higher rates of return to invest more in the particular country, reflecting both the willingness of consumers to postpone consumption by investing today and a portfolio analysis for savers. The initial equilibrium capital stock, shown as $K_{0}$, is not at the intersection of the supply and demand curves for capital, since we assume that the country faces a risk premium. On average, investors earn $r_{0}$ on their investments, but due to the uncertainty involved, they act as if earning an expected return of $\mathrm{r}_{0}$ with uncertainty were equivalent to earning $r_{0}-d_{0}$ with certainty (here $d_{0}$ is the country's risk premium).

Joining the European Union can affect the position of the demand curve and it can affect the size of the risk premium. The demand shift can come from many mechanisms. For instance, membership improves the country's market access to Europe's largest markets. If the country exports goods (e.g., manufactured goods)

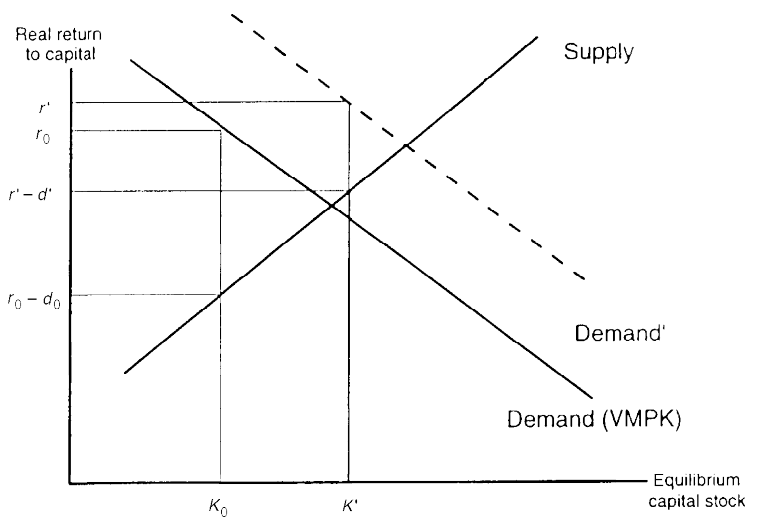

Figure 4. 
that are capital intensive relative to its non-traded goods (e.g., government services) then extra market access shifts up the nation's capital demand curve. This shift is illustrated in the diagram by a dashed line. (See Baldwin and Seghezza (1996) for a formal illustration of this trade-and-growth link and for many others.) The reduction in the risk premium can come from many sources, including a change in the underlying uncertainty (i.e., a bona fide stability of the economy) and an enhanced ability of investors to diversify risk (i.e., when domestic residents get improved access to wider capital markets). The post-enlargement risk premium, shown as $\mathrm{d}^{\prime}$ in the figure, is less than the pre-enlargement premium of $d_{0}$.

These two changes - a drop in the risk premium and an upward shift in the capital demand curve - result in an unambiguous increase in the capital stock (from $K_{0}$ to $K$ ), but an ambiguous effect on the real rate of return. To see this, note that as we have drawn it, the real return rises from $r_{0}$ to $r^{\prime}$, but if we had eliminated the risk premium altogether, we would have predicted a drop from $r_{0}$ to the point where the new demand and old supply curves intersect.

There are a few other things to note. First, the upward demand shift will normally be associated with an increase in the profitability of existing capital. This should show up in the average behaviour of the stock market, as long as the stock market reflects a broad sample of firms. The caveat comes from the fact that liberalization almost always harms some firms and sectors, even when it is beneficial to the nation as a whole. If the stock market is dominated by, say, state-controlled white elephants that will face increased pressure in a more liberal economy, then enlargement may be accompanied by a drop in the stock market index. Second, the diagram does not distinguish between domestic and foreign investors. An improvement in the national investment climate should attract more investment from both sources. This is likely to leave three kinds of 'footprint' in the data. The investment-to-GDP ratio should rise, the current account should deteriorate as more foreign funds come in, and the net direct investment figures should improve. Finally, note that all of these initial effects eventually wear off as the capital stock adjusts to its new level.

3.4.4. Historical data. We turn now to the evidence for the six countries that joined the EU during the 1973, 1981 and 1986 enlargements. Figure 5 shows the current account deficits for the 1973 entrants (Denmark, Ireland and the UK), the 1981 entrant (Greece) and the 1986 entrants (Portugal and Spain). For the six, entry was generally accompanied by an increase in capital inflows, although the pattern is certainly not stark. For instance, when we calculate the mean current account deficit for each entrant during the five years preceding accession, and the mean for the year of accession plus five years, we see that in all cases except Portugal the post-accession capital inflow is larger.

Figure 6 shows the change in stock market indices for the six entrants. The Iberian enlargement was clearly accompanied by a stock market boom, while the Greek accession did not produce such a result. The evidence for the 1973 

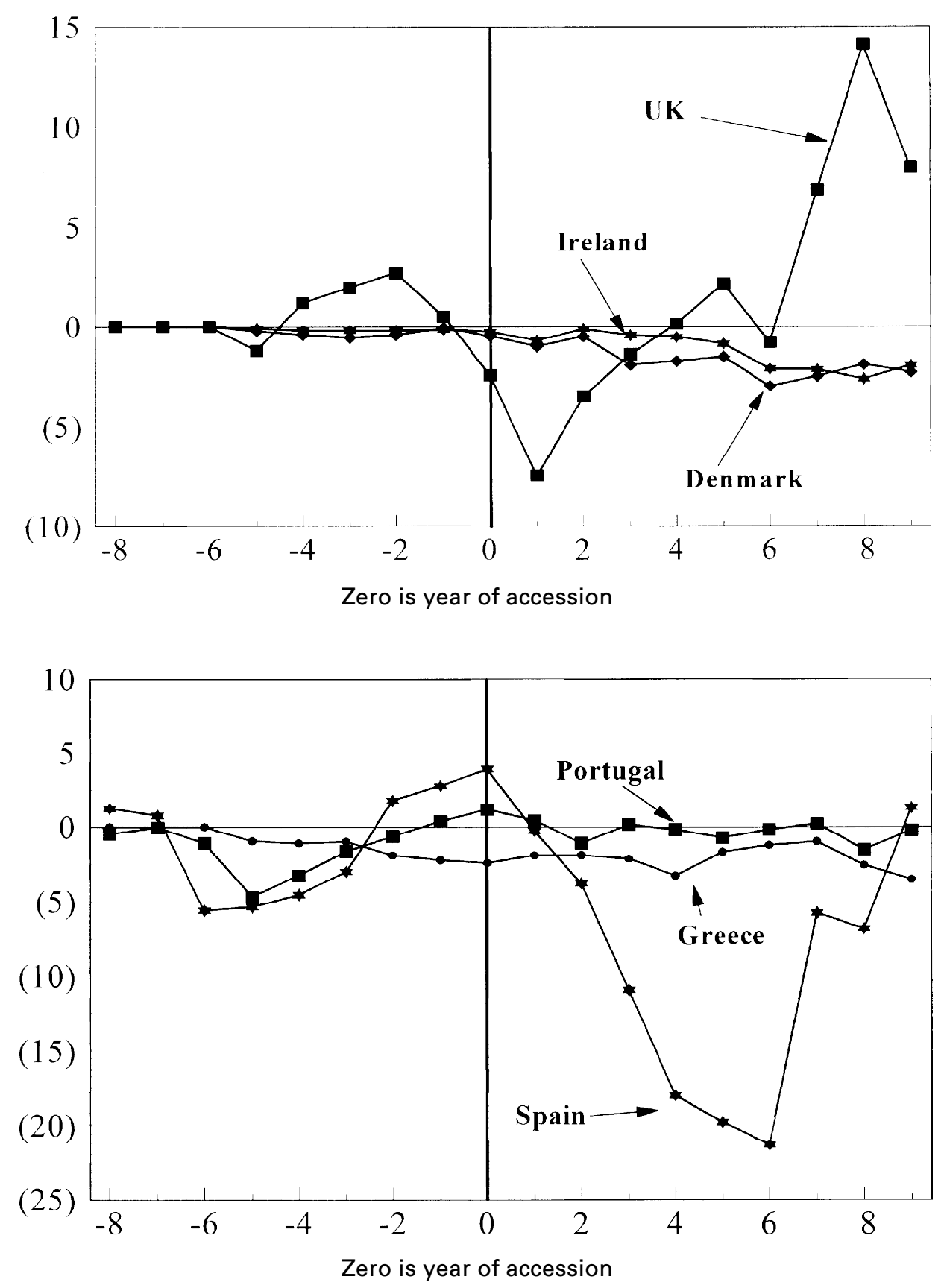

Figure 5. Current accounts for 1973, 1981 and 1986 entrants (8 years pre- and 9 years post-accession where data permit)

Source: IMF IFS databank. 


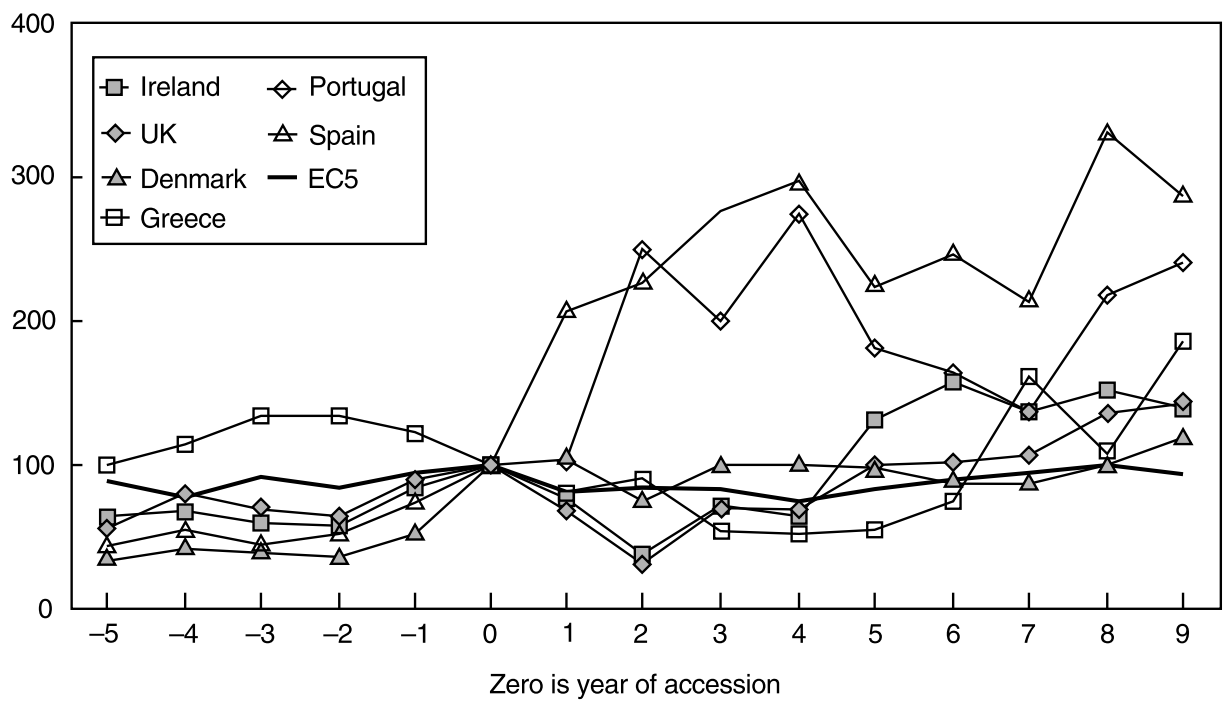

Figure 6. Stock market indices $($ accession year $=100)$

enlargement is much more confused - at least in part due to the unsettled macroeconomic environment of the early 1970s (the first oil price shock and rising inflation). To provide a benchmark, we also plot the GDP-weighted average movement of the EC5 stock markets (the EC6 less Luxembourg, for which data are available only from 1970). We see that the three entrants (Denmark, Ireland and the UK) did no better than average for the first few years. Further out, however, say nine years after membership, Ireland is doing much better than the average of incumbents. This fits in with our general idea that enlargement is likely to have the greatest impact on the countries that are economically the furthest behind the EU incumbents: namely, Ireland, Greece, Portugal and Spain. When it comes to stock market data, Greece is the exception among the poor entrants. As we shall see, the poor performance of Greece is echoed in several other indicators. To us this indicates that EU membership provides an opportunity for poor countries to catch up. There is, however, nothing automatic about the benefits.

The real interest data are much harder to interpret. As our theoretical discussion indicated, the combination of increased demand and reduced risk premium can result in either an increase or a decrease in real rates. Moreover, inspection of the data shows examples of both, so we do not provide a plot of the data. In brief, we find that the Iberians seem to have experienced a rise in real rates, but the pattern is much less clear for the other four nations.

Finally, Figure 7 shows the investment-to-GDP ratios (gross fixed business investment as a share of GDP) for all six entrants. Until the mid-1970s, Portugal and Spain were under dictatorships that typically ruled the economies with a heavy and sometimes arbitrary hand. Investment in these countries was consequently a risky business for those without close connections to the dictators. The end of the Iberian 


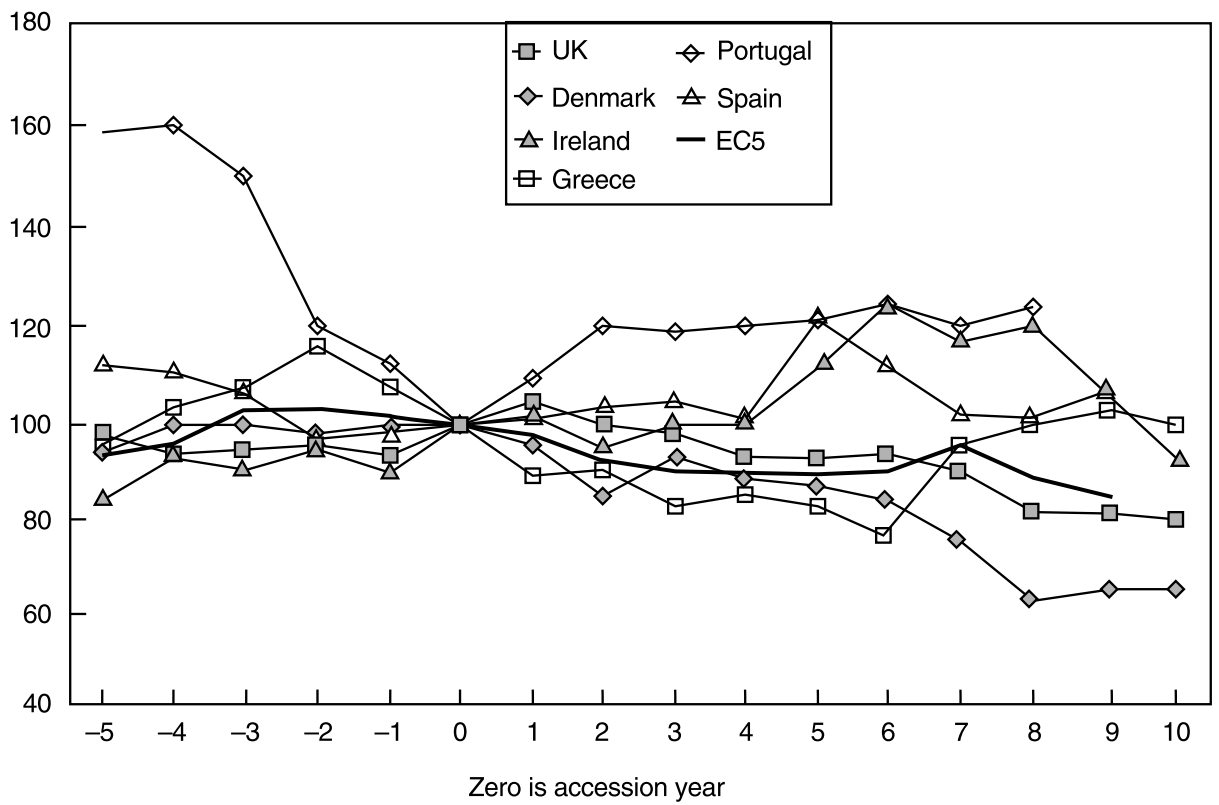

Figure 7. Investment to GDP ratios $($ accession year $=100)$

dictatorships and their EU membership bids transformed the investment climate on the Iberian peninsula. As the figure shows, the change in the Portuguese investment rate is especially marked around the beginning of accession talks in 1978. The talks dragged on, however, proving much more difficult than foreseen. The final outcome was not clear (at least for Spain) until 1984-5. The accession treaties were finally signed in 1985, with entry occurring in 1986. It is interesting to note that the investment rates in Portugal move in tandem with progress in the membership talks. Spain's investment rate did not pick up until membership was virtually assured. Recent years have seen the Iberian investment rates converging towards the EU averages. It seems, therefore, that the investment boost was transitional. The figure shows that Ireland experienced a similar investment boom during the decade following its accession. For Greece, however, accession had little impact on investment.

Clearly this evidence does not prove that EU membership is good for investment. Nor does it justify our specific quantitative assumption for the effect of accession on country risk. It does, however, provide a prima facie case that EU accession can be helpful in encouraging investment in poor entrants (namely Spain, Portugal and Ireland) and support for the assertion that the Iberian investment-led growth in the 1980s was greatly boosted by the prospect of EU membership. An important caveat is that EU membership in the mid-1980s involved far fewer constraints on domestic policy than it does now. Neither the single market programme nor monetary union were faits accomplis at that point. 
3.4.5. Simulation results. Table 4 presents the aggregate impact of enlargement under the less conservative scenario. Note first that the impact on the EU15 is almost unchanged from the conservative case - under both scenarios, the EU15 gain about ECU10 billion. The same holds true for the EFTA3 and the ex-USSR. The big change is the gain for the CEECs themselves. This should not be a surprising result, since the assumed risk premium reduction impacts primarily on the CEECs' capital stock. The projected gain - about ECU30 billion - is enormous by the standards of similar simulation models. Most of the extra real income gain comes from the estimated 68\% rise in the CEEG capital stock (the CEEC capital stock rises by only $1.2 \%$ in the conservative scenario).

Sensitivity analyses of the less conservative scenario are shown in Table 5. The two most arbitrary assumptions in the less conservative scenario are the trade cost reduction and the size of the risk premium reduction. First, still assuming that membership lowers east-west trading cost by $10 \%$, we consider different shocks to the risk premium on central European investment ranging from $0 \%$ (this is equivalent to the conservative scenario) to $15 \%$ (the less conservative scenario). The first column in Table 5 (top panel) shows that the real income gain of the CEECs falls from ECU30.1 billion to 6.2 billion as the risk premium reduction goes from $15 \%$ to $5 \%$. The second column of the top panel shows that the consequences for the EU15 are much less. Second, we hold the risk premium shock at the less conservative scenario assumption of $15 \%$ and vary the trade cost reduction assumption. The results for both the EU15 and the CEEC7 (shown in the bottom panel of the table) are little affected by these changes.

That the effects on the CEECs remain large under different scenarios is important. The CEECs are already keen on joining the European Union for geopolitical reasons, so even the finding of a significant negative economic impact would be unlikely to affect their ardour for rapid membership. The same cannot be said for the EU15 and it is the EU15 who will decide the timing of enlargement. True, the EU15 are all committed to admitting the CEECs eventually, but their perception of the large economic costs of eastern enlargement seems to have made them reluctant to hasten the enlargement process.

Table 4. Real income effects: less conservative case

\begin{tabular}{lcc}
\hline \hline & $\begin{array}{c}\text { Real income change } \\
\text { (1992 ECUbn, } \\
\text { change from base case) }\end{array}$ & $\begin{array}{c}\text { Real income change } \\
\text { (\% change } \\
\text { from base case) }\end{array}$ \\
\hline CEEC7 & 30.1 & 18.8 \\
EU15 & 11.2 & 0.2 \\
EFTA3 & 0.1 & 0.1 \\
Ex-USSR & 2.1 & 0.6 \\
\hline \hline
\end{tabular}

Notes: This is a comparative steady-state exercise, so real income changes are not equivalent to utility-based welfare changes. EFTA3 is Norway, Iceland and the Swiss-Liechtenstein customs union.

Source: Authors' calculations. 
Table 5. Sensitivity analysis: real income effects

(1992 ECUbn change from base case)

\begin{tabular}{lcr}
\hline \hline & CEEC7 & EU15 \\
\hline Different risk premium shocks & & \\
0\% reduction & 2.5 & 9.8 \\
$5 \%$ reduction & 6.2 & 10.0 \\
10\% reduction & 14.5 & 10.3 \\
15\% reduction & 30.1 & 11.2 \\
& & \\
Trade cost reductions (with 15\% risk premium reduction) & \\
5\% reduction & 29.5 & 10.2 \\
10\% reduction & 30.1 & 11.2 \\
15\% reduction & 30.4 & 11.8 \\
\hline \hline
\end{tabular}

Notes: These are a comparative steady-state exercise, so real income changes are not equivalent to utility-based welfare changes. EFTA3 is Norway, Iceland and the Swiss-Liechtenstein customs union.

Source: Authors' calculations.

\subsection{Sharing out the economic benefits}

Our simulation model does not contain individual member states, so we cannot determine how the aggregate gain is distributed among the various EU15 nations. This is, nonetheless, an important political issue, so we present some back-ofthe-envelope calculations. Under both scenarios, the simulation breaks down changes in the EU15's GDP by sector. As a first step, we distribute these sectoral changes to member states using the importance of each member state's sector (as measured by value added) in the EU15 sector totals. These changes do not add up to the EU15's aggregate real income gain, since consumers also gain from price changes. The difference - which is due to projected price changes in the enlarged EU - is allocated among incumbent member states according to their share of EU15 income. The results of this admittedly rudimentary procedure are listed in Table $6 .{ }^{4}$ (The shares are very similar under the two scenarios, so we report only the estimated distribution for our preferred scenario - the less conservative estimates.)

The gains are distributed in a very uneven fashion. The shares of Germany, France and the UK sum to more than two-thirds of the whole EGU11.2 billion that the EU15 are projected to gain. Given Germany's overall size and dominance of the EU sectors that are projected to expand the most (transport equipment and capital goods), it is not surprising that Germany gets a third of the total. Both France and

\footnotetext{
${ }^{4}$ An alternative set of calculations, based on the approximation of member state welfare effects through simple partial
} equilibrium estimates based on member country trade effects, leads to the same qualitative pattern of results. 
Table 6. Distribution of gains among EU incumbents (change from base case, less conservative scenario)

\begin{tabular}{lcc}
\hline \hline & 1992 ECUbn & \% of EU15 total \\
\hline Germany & 3.8 & 33.8 \\
France & 2.2 & 19.3 \\
UK & 1.6 & 14.1 \\
Italy & 1.0 & 8.5 \\
Spain & 0.8 & 7.0 \\
Netherlands & 0.5 & 4.6 \\
Sweden & 0.4 & 3.9 \\
Belgium-Luxembourg & 0.3 & 2.6 \\
Austria & 0.3 & 2.6 \\
Denmark & 0.2 & 1.9 \\
Finland & 0.2 & 1.4 \\
Ireland & 0.0 & 0.3 \\
Greece & 0.0 & 0.3 \\
Portugal & -0.0 & -0.4 \\
& & 100.0 \\
EU15 & 11.2 & \\
\hline \hline
\end{tabular}

Note: See text for methodology.

Source: Authors' calculations.

the UK get double-digit shares (19\% and 14\% respectively) - again not surprising, given the size and sectoral composition of the French and UK economies. The Netherlands and Spain each take between about $5 \%$ and $10 \%$ of the total gain. The Dutch figure comes largely from the fact that this economy focuses on sectors whose GDPs rise with enlargement. The high Spanish figure stems partly from the sharing out of the sectoral GDP gains (the Spanish economy is quite diversified) and partly from the fact that the fairly large size of the Spanish economy ensures that Spain takes a healthy slice of the consumer gains stemming from lower prices. Each of the other incumbents gets less than $5 \%$ of the total gain. Portugal is the only incumbent that is estimated to lose on these narrow economic grounds. This loss reflects Portugal's heavy reliance on textiles (this is the EU sector that takes the biggest hit from enlargement according to our projections). Portugal's loss, however, is vanishingly small and, given the inherent imprecision of CGE models, it is best to think of this figure as zero.

\section{THE BUDGET COST OF A VISEGRAD ENLARGEMENT IN 2000}

Since Baldwin et al. (1992) and Baldwin (1994), the costs to the EU budget have acquired a disproportionate prominence in the public debate on eastern enlargement. Yet they are important politically, and some extreme estimates have aroused political reaction. This section quantifies the budget burden by reviewing and evaluating an extensive literature on this issue. It also makes a novel contribution by 
using a 'power politics' approach to estimating the budget impact. Before turning to the estimates, we present the essentials of the EU's budget. ${ }^{5}$

\subsection{The EU budget: a primer}

Table 7 shows that two items dominate the spending side of the EU budget, the common agricultural policy (CAP) and structural spending (the Structural Funds and the Cohesion Fund). Together these account for over 80\% of all EU spending. The importance of structural and agriculture spending accurately reflects their importance in the Union. Dr Pangloss would say this spending helps various regions and groups adjust to the pressures of European economic integration. Machiavelli would say these funds are payoffs to politically powerful special interest groups that might otherwise oppose European integration. Both would agree that these programmes are a key ingredient in the political cement that binds member states into a union and allows the EU to be much more than a free trade area. Eastern enlargement will greatly increase the EU's economic diversity and thereby multiply the centrifugal forces. Structural and farm spending will continue to be needed to contain them.

Revenue is generated from four main sources. The most important is VAT receipts. According to agreed rules, the Union gets a slice of each member's national VAT revenue. (The precise rules are very complex; see Strasser (1992) for details.) The second and third sources, namely tariff revenue and agricultural levies (variable tariffs until recently), are quite straightforward: all tariff revenue accrues directly to the EU. The fourth major income source is based on members' GNPs and is used to 'top up' revenue to balance accounts (the budget must be balanced each year). The net effect of these four sources is a modestly progressive tax rate.

Table 7. EU budget, 1994

\begin{tabular}{lrlr}
\hline \multicolumn{1}{c}{ Revenue } & \multicolumn{2}{c}{ Spending } \\
\hline VAT & $48.4 \%$ & CAP & $49.4 \%$ \\
Tariffs & $18.4 \%$ & Structural Funds & $31.9 \%$ \\
Agricultural levies & $3.3 \%$ & R \& D & $4.4 \%$ \\
GNP based & $27.4 \%$ & Administration & $5.3 \%$ \\
Other & $2.1 \%$ & Foreign aid & $6.7 \%$ \\
& & Other & $2.3 \%$ \\
Total (ECUbn) & 68.6 & Total (ECUbn) & 67.6 \\
\hline \hline
\end{tabular}

Source: EU Court of Auditors (1995).

\footnotetext{
${ }^{5}$ See El-Agraa (1994) and EU Court of Auditors (1995) for more details. See Laffan and Shackleton (1996) for an excellent general discussion of the budget, budget politics and a history of the EU budget conflicts that followed previous enlargements.
} 
4.1.1. Structural Funds. The Structural Funds are large transfers to the disadvantaged member states and regions. The funds are explicitly aimed at encouraging convergence of per capita income levels. Spending is classified by the nature of the problem it is aimed at. The regions or groups that are the focus of these aims are called Objectives 1-6. The most important of these - Objective 1 - accounts for two-thirds of all structural spending. ${ }^{6}$ Also important is the Cohesion Fund for countries with national income per capita less than $90 \%$ of the EU average; in practice this rule was set to ensure that only the poor-4 (Greece, Ireland, Portugal and Spain) qualified. Structural Funds spending is by far the most rapidly growing budget item since 1988. When the current budget plan ends in 1999, this spending should amount to ECU33 billion - a fourfold increase from 1988. Given that CEEC per capita incomes are all below that of the poorest of the EU15 (Greece), the most relevant aspect of this expenditure is its close link with per capita incomes.

4.1.2. Common agricultural policy. The CAP is a very complicated, expensive set of policies aimed at raising income and output of the EU farm sector. This support takes two main forms: (1) price floors (every six months agriculture ministers gather to set the 'correct' prices for farm products) and (2) direct payments ('compensation') to farmers. The direct payments are linked to the price floors, in the sense that they were intended to buy off opposition to the 1992 MacSharry reforms that brought the price floors down towards market-clearing levels. Compensation payments are linked to historical production on land that is taken out of production.

The price floors are maintained with two types of policy: protection and market intervention. Protection is insufficient, since the EU price floors are above the zeroimport level. Consequently, the EU must buy up the food shunned by EU consumers at these above-market-clearing prices. This 'excess' food is disposed of in one of three ways. It is stored until it rots; it is dumped on the EU market (e.g., the EU subsidizes wheat purchases by EU bakeries); or it is dumped (i.e., sold below cost) on world markets. The rising costs of this 'intervention' led to the introduction of production quotas in some products. Since 1984 the food surplus is restricted by quotas per farm (e.g., for milk), and by requiring farmers not to grow food on part of their land. More than half the cost of this support is paid for directly by consumers via the 'hidden tax' of protectionism, according to OECD (1992). The

\footnotetext{
${ }^{6}$ 'Objective 1' regions are defined as regions with per capita incomes that are less than $75 \%$ of the EU average, and over $20 \%$ of the current EU population is eligible under this objective. This spending is aimed at improving infrastructure and local training. 'Objective 2' regions are those that suffer from a decline of traditional industries such as coal and steel. Over 45 million of the EU's 340 million citizens live in these regions. The spending under this objective is aimed at creating jobs, improving the environment, developing $\mathrm{R} \& \mathrm{D}$ and renovating land and buildings. 'Objective 5b' regions are rural areas, like the Highlands of Scotland, that are too rich for Objective 1 but still face development difficulties. The other objectives are aimed at the long-term unemployed (Objective 3), unemployed youth (Objective 4); backward farms (Objective 5a), the eastern states of Germany (Regulation No. 3575/90) and Arctic regions (Objective 6).
} 
rest is paid for out of the EU budget - more precisely, from the European Agriculture Guidance and Guarantee Fund (EAGGF).

The budget costs are mostly linked to food surpluses (output less consumption). The consumption side is straightforward, since food demand varies with income and prices in a predictable manner. The output side is essentially intractable: the hard part is to guess how much CEEG farm yields would rise under the CAP, which depends on the extent to which guaranteed prices and sales would stimulate technology transfers and foreign direct investment by western agro-corporations.

\subsection{A survey of existing estimates}

There is an extensive literature on the cost of eastern enlargement. Three Cs CAP, cohesion and contributions - dominate the calculations. Of the three, the level of the CEECs' national contributions as members is least controversial. All member states put in about 1\% of GDP. The big debates are over CAP and cohesion spending. We turn first to the studies on cohesion spending.

4.2.1. Cohesion cash. The best-known early estimation (Courchene et al., 1993) was based on a simple extrapolation of the current level of per capita Structural Funds (SF) receipts in the two poorest incumbents. While per capita SF receipts vary widely among member states (see Table 8), Courchene et al. (1993) settled on a rounded-off average of Greek and Portuguese receipts: namely, ECU200 per person. The Edinburgh summit promised to double this by 1999, so the figure of ECU400

Table 8. Structural Funds allocation, 1993

\begin{tabular}{lccc}
\hline \hline & $\begin{array}{c}\text { Total SF } \\
\text { (ECUbn) }\end{array}$ & $\begin{array}{c}\text { Per capita SF } \\
\text { (ECU) }\end{array}$ & $\begin{array}{c}\text { SF as \% of } \\
\text { GNP }\end{array}$ \\
\hline Ireland & 1088 & 311 & 2.8 \\
Portugal & 2327 & 233 & 2.6 \\
Greece & 1897 & 184 & 2.5 \\
Spain & 2971 & 76 & 0.7 \\
Italy & 3398 & 59 & 0.4 \\
France & 1682 & 30 & 0.2 \\
UK & 1213 & 21 & 0.1 \\
Luxembourg & 14 & 43 & 0.1 \\
Denmark & 107 & 21 & 0.1 \\
Belgium & 187 & 19 & 0.1 \\
Netherlands & 206 & 14 & 0.1 \\
Germany & 870 & 11 & 0.1 \\
EU12 & 15962 & 47 & \\
Portugal and & & & \\
Greece average & & 208 & \\
Poor-4 average & 7788 & 132 & \\
\hline \hline
\end{tabular}

Note: Structural Funds (SF) include EAGGF, Regional and Social Funds. Source: Court of Auditors, Report on 1993. GNP/pop. from World Bank. 
Table 9. Projected Structural Funds spending

\begin{tabular}{lccc}
\hline \hline & $\begin{array}{c}\text { Projection assuming } \\
\text { ECU400 per capita } \\
\text { (EGUbn) }\end{array}$ & $\begin{array}{c}\text { Implied aid } \\
\text { absorption } \\
(\%)\end{array}$ & $\begin{array}{c}\text { Projection assuming } \\
\text { 5\% of GDP } \\
\text { in 2000 } \\
\text { (ECUbn) }\end{array}$ \\
\hline Czech Republic & 4.1 & 9.3 & 2.2 \\
Slovak Republic & 2.1 & 13.3 & 0.8 \\
Hungary & 4.1 & 7.8 & 2.7 \\
Poland & 15.4 & 12.4 & 6.2 \\
Slovenia & 0.8 & 4.2 & 0.9 \\
Visegrad total & 26.6 & & 12.8 \\
\hline \hline
\end{tabular}

Note: See text for methodology.

per person was used to project enlargement costs. Just for the 64 million people in the Visegrad-4 countries, this amounts to ECU26 billion.

This widely influential estimate has been questioned by the European Commission in its Interim Report on eastern enlargement (1995a), and by independent analysts (e.g., Grabbe and Hughes, 1996). The primary criticism points out that ECU400 per capita implies unrealistically high levels of aid absorption for the CEECs. Moreover, CEEG governments under severe fiscal pressure would be unable to provide 'matching funds' on anything like the scale that current regulations would require. As Table 9 shows, even with their current low income levels boosted by sustained 5\% growth, ECU400 per person would amount to $10-15 \%$ of these countries' GNPs in 2000. Suppose we take $5 \%$ of GNP as a more realistic upper bound. The projected Visegrad SF spending under this rule amounts to EGU12.8 billion.

4.2.2. How to spend the money. Current incumbents are having trouble spending all the SF allocated to them: in 1994 actual expenditures were only $70 \%$ of the planned expenditures, partly because of the 'matching funds' constraint. Yet the structural problems facing the transition economies dwarf those of Greece and Portugal. One can easily think of ways of spending cash productively on the GEECs. For example, the human capital infrastructure needs updating. Expensive training courses in western Europe and consultancy fees for western experts could rapidly soak up ECU400 per person per year. The environmental infrastructure could also devour large amounts. Lastly, one might argue that the CEECs should be exempted from making national contributions. To put numbers to this, say Poland managed to spend as much as Ireland on traditional Objective 1 projects (2.8\% of GNP) and was exempted from national contributions (1\% of GNP). Per Pole, this would account for ECU74 in Objective 1 aid and EGU27 in exempted contributions. Next suppose Poland sent $0.5 \%$ of its population on training courses in western Europe and paid western consultancies to train another $0.5 \%$ of its population in-country. Taking the 
EU's HCM grants in the early 1990s as a landmark (i.e., ECU40 000 per year per participant) for this training, we get to an average of ECU400 per Pole for training. All this is without considering spending on environmental clean-up. Moreover, as section 4.3 shows, the EU has been willing to change spending rules for new entrants.

Adding in new poor countries will lower the EU average income. Recalling that Objective 1 status (this status qualifies the region for big transfers) requires a region to be below $75 \%$ of the EU average, we see that enlargement will necessarily lift some currently eligible regions over the $75 \%$ line! While politics makes this unlikely, the possibility does suggest a source of savings on SF spending. Begg (1996) calculates that an aggregate population of 45 million would lose their Objective 1 standing if the ten CEECs were admitted. Spain would also lose its Cohesion Fund status. We do not attempt to calculate these savings because we believe that the rules will probably be changed to maintain the incumbent regions' Objective 1 status. All in all, therefore, it seems that a 5\% of GNP limit is the most reasonable estimate. Ireland, Greece and Portugal have very different per capita income levels, yet each of them receives approximately $2.5 \%$ of its GNP in SF. Doubling that rate, we take the implied ECU13 billion for the Visegrad-4 as the consensus estimate.

4.2.3. CAP cash. The debate on the cost of extending the CAP to the Visegrad-4 is far more complex, due to the complexity of the CAP itself, the lack of accurate data on CEEC farms, and the rapidly evolving nature of eastern agriculture. The range of estimates is correspondingly wide. Table 10 shows estimates for the CAP cost of a Visegrad enlargement that range from ECU4 billion (Brenton and Gros, 1993) to ECU37 billion (Anderson and Tyers, 1993). The more recent estimates, however, have converged significantly. There are two main reasons for this. First, much better data became available with Jackson and Swinnen (1994). Second, the impact of the MacSharry reforms was much clearer after a few years of implementation. For these reasons, all 1995 and 1996 estimates put the cost at ECU5-15 billion with ECU10 billion being a fairly representative estimate. ${ }^{7}$

Tangermann (1996) points out that two key elements lead to the wide range of estimates. First is the assumption concerning eastern farm productivity. The CEEC farm sectors, like every other sector, experienced a sharp decline in output during the early transition years (however, industrial output fell even more quickly than farm output). The reasons were abnormal climatic conditions in 1992 and 1993, a sharp drop in real output prices accompanied by a sharp rise in input prices, and disruption of marketing infrastructure (see EG, 1995b). The low-end estimates essentially assume that this drop is permanent and would not be reversed by the $40-50 \%$ price rises that would come with the CAP. The high-end estimates assume

${ }^{7}$ Despite the wide range of numerical estimates, virtually all independent authors agree on a key qualitative conclusion: the CAP must be reformed before the eastern enlargement. 
Table 10. Estimated GAP cost of eastern enlargement (EGUbn)

\begin{tabular}{lrr}
\hline \hline Study & Visegrad-4 & CEEC10 \\
\hline Anderson and Tyers (1995) & 37 & \\
Tyers (1994) & 34 & $32-55$ \\
Brenton and Gros (1993) & $4-31$ & \\
Mahé (1995) & $6-16$ & 12 \\
Tangermann and Josling (1994) & $9-14$ & $9-23$ \\
EC (1995c) & & \\
Slater and Atkinson (1995) & $5-15$ & \\
Tangermann (1996) & $13-15$ & \\
\hline \hline
\end{tabular}

Note: Slovenia joined the Visegrad-4 after the studies were completed. Sources: See References.

that massive technological transfers and/or direct investment by western agroindustry would raise eastern yields to western levels. The second factor is assumptions about CAP reform. The earliest estimates ignored the MacSharry reforms, especially supply controls, set-asides and compensation payments.

CAP costs face two external limitations, neither completely immutable, but both politically difficult to alter. The first is the EU's own cap on CAP spending increases. An EU rule - in effect since 1988 - limits CAP spending to rise not faster than $74 \%$ of the Union's GDP growth. If this rule, which was respected during the last enlargement, were applied to a Visegrad enlargement in 2000, CAP spending could rise by no more than about EGU0.9 billion. ${ }^{8}$ Plainly this rule will be binding. The second involves the GATT commitments undertaken by the GEEGs during the Uruguay Round. Most GEEGs bound their protection rates and subsidized export levels far more stringently than did the EU. Thus, according to Tangermann (1996), even the conservative estimates suggest that the Visegrad-4 would violate their GATT cereals export commitments by $400-500 \%$ under the CAP. Of course, Article 24 of GATT would in principle allow the CEEGs to break these commitments when they join the EU's customs union, but non-European farm exporters will demand compensation. For instance, the EU awarded compensation to the US farm interests following the 1986 and 1995 enlargements.

4.2.4. How reasonable are the estimates? There is a simple test of the reasonableness of the GAP estimates. Table 11 shows the CAP cash per farmer and per hectare in the EU12 in 1994. Countries are ranked in descending order of average receipts per farmer, from Belgium's spectacular 12300 to Portugal's modest

\footnotetext{
${ }^{8}$ Using the Commission's Interim Report statistics on Visegrad and EU15 GDPs, and assuming 5\% and 2\% growth for the Visegrad-4 and EU15 respectively, the Visegrad enlargement would increase EU GDP by only $3 \%$, so CAP spending can rise by only 2.22\%. The current Financial Perspective foresees CAP expenditures of ECU38.4 billion.
} 
Table 11. Cost estimates in perspective, 1994 data

\begin{tabular}{lccccc}
\hline \hline & $\begin{array}{c}\text { CAP cash } \\
(\text { ECUm })\end{array}$ & $\begin{array}{c}\text { Farmers } \\
(\mathrm{m})\end{array}$ & $\begin{array}{c}\text { EGU per } \\
\text { farmer }\end{array}$ & $\begin{array}{c}\text { Farm land } \\
(\mathrm{m} \text { hectares })\end{array}$ & $\begin{array}{c}\text { EGU per } \\
\text { hectare }\end{array}$ \\
\hline B & 1229 & 0.1 & 12290 & 1.3 & 914 \\
IRL & 1658 & 0.1 & 11845 & 4.3 & 388 \\
DK & 1321 & 0.2 & 8806 & 2.7 & 482 \\
F & 8621 & 1.0 & 8226 & 27.0 & 319 \\
NL & 1948 & 0.3 & 7379 & 2.0 & 967 \\
D & 6159 & 1.0 & 5951 & 17.0 & 362 \\
EU12 & $\mathbf{3 9 9 0 9}$ & $\mathbf{7 . 1}$ & $\mathbf{5 6 2 1}$ & $\mathbf{1 1 7 . 9}$ & $\mathbf{3 3 9}$ \\
UK & 3070 & 0.6 & 5433 & 16.4 & 187 \\
E & 4953 & 1.2 & 4303 & 24.7 & 200 \\
I & 6724 & 1.6 & 4277 & 14.7 & 456 \\
GR & 2985 & 0.8 & 3779 & 3.5 & 844 \\
L & 22 & 0.0 & 3650 & 0.1 & 172 \\
P & 1219 & 0.8 & 1514 & 4.0 & 309 \\
High-, medium- and low-cost estimates for Visegrad enlargement & & 31.4 & 478 \\
Visegrad-4 high & 15000 & 4.50 & 3332 & 31.4 & 318 \\
Visegrad-4 medium & 10000 & 4.50 & 2221 & 31.4 & 159 \\
Visegrad-4 low & 5000 & 4.50 & 1111 & \\
\hline \hline
\end{tabular}

Notes: For B, DK, L and P, number of farmers for 1990. Slovenia joined the Visegrad-4 after the studies were completed.

Sources: EC (1995a, c).

$1500 .^{9}$ The bottom of the ECU5-15 billion estimated cost range assumes that CEEG farmers will get less than $20 \%$ of the EU12 average, and the top assumes they will get about $60 \%$ of the EU12 average. Yet Visegrad-4 climatic conditions and geography suggest that their farm output should resemble that of a northern EU incumbent, like Germany or Denmark. This is important, since the CAP is heavily biased towards northern European farm products (notice the correlation between latitude and ECU per farmer). In other words, one might be tempted to compare Polish farmers with German farmers. Such a temptation should be resisted, however, since most CAP payments are linked to output. The low productivity of Visegrad-4 farmers therefore suggests low CAP receipts. Moreover, the low productivity of Visegrad-4 farmers is quite in line with the low productivity of their workers in other sectors (by definition, the low GDP per capita tells us that they have low labour productivity).

The ECU per hectare figures in the final column of Table 11 may prove a more reliable guide to gauging reasonableness. One can argue that capital and technology are more mobile than workers (farmers in this case), so east-west land productivity differentials should equalize faster than east-west labour productivities. The EGU

${ }^{9}$ Since most CAP cash is linked to output, the distribution of receipts is heavily skewed towards large industrial farmers. The average therefore combines a few very rich farmers with many modest-income farmers. EC (1994b), for instance, estimated that $80 \%$ of the cash goes to $20 \%$ of the farmers. 
per hectare measure makes the estimated cost range look eminently reasonable. It brackets, for instance, the figures for the UK and Denmark. Of course, the landbased figure has its own faults: a great deal of CAP money goes to non-landintensive products such as milk and butter.

4.2.5. Consensus estimates? In summary, the range of estimates is now remarkably narrow. The estimates from a Visegrad-4 enlargement of ECU10 billion for CAP spending and ECU13 billion for cohesion spending seem the most sensible. Assuming these countries grow at 6\% per annum on average from 1994 to 2000, their combined GDP should be about ECU440 billion, so accession in the year 2000 would imply contributions of about ECU4 billion. The net cost should be about ECU19 billion, 19\% of what the 1999 budget would be without enlargement.

\subsection{Machiavelli's rebuttal: the EU budget and power politics}

All the budget estimates cited above assume that the status quo EU spending rules will continue after the eastern enlargement. While it is easy to see why authors adopted such an assumption, it is quite wrong. This section presents some theory, four examples from historical enlargements, and a bit of econometrics to make a point that may seem obvious to practising policy-makers: power politics dictate the EU's budget. If one accepts this point of view, and one is willing to assume that the rules governing the allocation of voting rights to $\mathrm{EU}$ members will remain unchanged, then we have an alternative approach to projecting budget costs. It is important to keep in mind that this alternative approach assumes that the ongoing Inter-Governmental Conference will not significantly alter voting rules.

4.3.1. A little theory: the political economy approach. The 'dismal science' supposes that people work, save and consume in order to maximize their own wellbeing. When the dismal science is applied to the arena of policy, it is called political economy theory, or political equilibrium analysis. In this arena, policy-makers choose policies to maximize their own well-being, which consists of staying in office. While this approach is a gross oversimplification, it provides powerful insights into the impact that eastern enlargement will have on the EU budget.

The EU budget is decided by a complex process, but we focus on the Council of Ministers. The Council has two main decision rules. On very important issues, such as the adoption of the EU fundamental law (e.g., the Maastricht Treaty and the Single European Act), enlargement or fiscal questions, decisions must be unanimous. Because the 'winning' coalition must include everyone, each potential opponent must be 'bought off'. Many other issues, however, are decided on the basis of a 'qualified majority': each country is assigned a certain number of votes, and a winning coalition need only have $71 \%$ of these votes. Of course, the Council decides many issues each year, so the possibility of 'horse trading' and 'back scratching' is 
great. Countries tend to trade their votes on issues that they view as minor, in exchange for support on an issue that they view as major, even if the two issues are totally unrelated.

These rules suggest two very precise definitions of power. The first - the so-called Shapley-Shubik index (SSI) - defines power as the ability of a country to turn a losing coalition into a winning coalition. This constitutes power, since a country that finds itself in such a pivotal situation can ask for something in return, such as extra budget spending for its citizens, or a rule change that favours its national firms. Formally, the SSI is the percentage of times that the country's votes would be pivotal. While a country's SSI index is roughly related to the country's share of votes, it is also influenced by the correlation of its voting behaviour with that of other countries and by the distribution of votes among other countries (see Kirman and Widgrén, 1995). The second measure is simply the country's number of votes. It is less elegant, but much easier to construct and understand. As we shall see for the EU12, the SSI performs slightly better than the vote-based measures.

\subsubsection{Power politics, historical enlargements and budget priorities: four}

examples. Turning from theory to practice, we shall argue that the political economy approach is useful in organizing our thinking about the budget impact of historical enlargements. In particular, we focus on four examples in which new entrants used their political power to alter EU spending rules in their favour.

UK accession. The EU's current budget system was created by budget treaties of 1970 and 1975. In particular, the 1970 agreement created the 'own resources' system of national contributions (described above). By making contributions more or less automatic, this prevented annual haggling over payments. According to Laffan and Shackleton (1996), 'the 1970 budget deal was designed to fix the rules before the UK, structurally disadvantaged by the agreement, became a member'. (The disadvantage, which stemmed from the small UK farming sector, meant the UK was a major net contributor, despite its below-average per capita income level). While this may overstate the case, we do know that the UK Labour government renegotiated the terms of accession in 1975. The solution adopted for the UK's large net contribution - the so-called Financial Mechanism - failed to work, however, and the issue caused problems until Margaret Thatcher won her famous rebate in 1984.

The lesson should be clear. In a democratic body like the EU, new entrants will use their newly granted political power to undo any accession terms that they feel are unjust. Moreover, the strategies used to alter the terms may be detrimental to the functioning of the organization. The UK's perception of injustice in the terms of accession led to almost a decade of political difficulties. Laffan and Shackleton (1996) write: 'Between 1979 and 1984 the member states and the EG institutions were locked in a protracted dispute about EG revenues and expenditure which contributed in no small way to the malaise and stagnation of the early 1980s.' 
The EFTA enlargement. During the recent enlargement negotiations with Austria, Finland and Sweden, Structural Funds spending rules were changed. A new spending criterion, Objective 6, was created to channel funds to remote regions in Finland and Sweden. Although the amounts are small, the principle is important. Under pre-1995 rules, Finland and Sweden would have received little from the Structural Funds or the CAP, and thus would have been significant net contributors to the budget. Towards the end of their accession talks, the EFTA4 (Austria, Finland, Norway and Sweden) won a number of rule changes that reduced their net contributions to a level well below what it would have been under status quo rules.

The political economy approach would explain this example using the anticipated voting power of the new entrants. Under EU rules, small countries are accorded far more votes per citizen than are large countries, so despite their small populations the entrants were projected to have almost one-sixth of Council votes. ${ }^{10}$ However, politicians rarely exercise raw power without providing a good rationale. In this case, the new entrants claimed that the pre-1995 rules were not designed to deal with their structural problems: namely, low population density in remote regions. The EU agreed, and the rules were changed. Of course, the same could be said $a$ fortiori about the CEECs. Existing EU rules are not designed to address the problems of very poor countries (the World Bank classifies Poland and the Czech Republic in the same income group as Tunisia and Panama), nor are they designed for the problems of economies in transition. Clearly, eastern enlargement will bring pressure to change the rules, and the EU has shown a willingness to invent new ways of providing structural funds to entrants.

The Iberian enlargement. The third example concerns the impact of the Iberian enlargement on structural spending. This has several illuminating aspects, some of which involve changes in spending levels and some of which involve changes in spending rules. The EU has always had poor regions (southern Italy, for example), but regions do not vote in the Council of Ministers. Since the 1974 accession of Ireland and that of Greece in 1981, the EU has had poor members. While these two entrants boosted structural spending, the changes were marginal. Big changes, however, accompanied the 1986 Iberian enlargement.

First, a group of incumbents (Greece, France and Italy) demanded special budget allocations in return for accepting the Iberians, the rationale being that the Iberians' southern agriculture was a threat to the Mediterranean incumbents. The result was the Integrated Mediterranean Programme. This created 3-7-year projects that cost about ECU6.6 billion, according to Allen (1996). A second, much larger change was the doubling of structural spending that accompanied the ratification of the 
Single European Act in mid-1987. ${ }^{11}$ Figure 8 provides some statistical evidence for the political economy approach by showing that there is a remarkable correlation between the spending on poor regions and the share of poor country votes in the Council. In fact, not only are the trends the same, but the levels of the two indices coincide pretty closely. A second remarkable feature is the way in which structural spending gains seem to squeeze down the CAP's spending share. While this win-lose relationship is an algebraic inevitability, given the dominance of the two items in the EU budget, it also reflects the realities of power politics.

Why did the 1986 enlargement change so much when the Irish and Greek accessions changed so little? Voting power provides one possible answer. Ireland had only 3 of 58 votes, Ireland and Greece together had only 8 of 63 votes, but the Iberian accession gave 21 of the 76 Council votes to the poor-4. Because this was only two votes shy of a blocking coalition, the Iberian enlargement constituted a major shift in the distribution of power. Not surprisingly, this led to a major reorientation in budget priorities.

Further instructive aspects of the Iberian accession involve two landmark budget agreements. In 1988, EU leaders agreed to limit the growth of CAP spending, and they set an upper bound on the EU budget as a percentage of GDP. The political economy approach would point to the newly powerful coalition of poor countries as

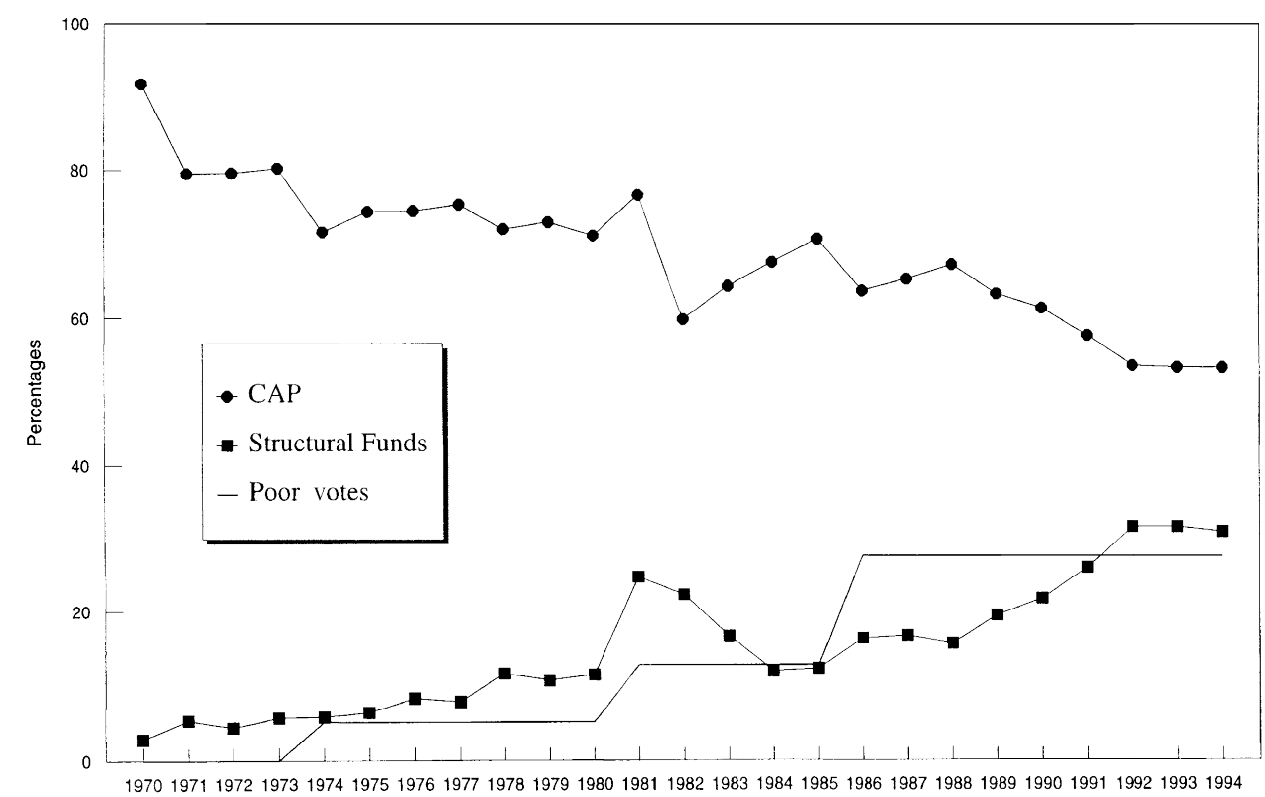

Figure 8. Voting power and spending shares, 1958-94

Sources: EG (1994a) and own calculations.

${ }^{11}$ The Council adopted the SEA treaty in 1986, but it was not ratified by all member states until mid-1987. 
the deep force behind these changes. The CAP is the Structural Funds' major competitor for EU cash, so anything that reduces CAP spending tends to free up moneys for the poor-4. The budget ceiling can likewise be explained. The jump in Structural Funds spending fundamentally changed the nature of the EU budget. Before the Iberians joined, CAP spending routinely accounted for $70 \%$ or more of the budget (see Figure 9) and, roughly speaking, the cost of the CAP dictated the size of the overall budget and national contributions. In those days, one could say that the EU budget was essentially a way of allowing rich northern European nations to subsidize each other's farmers. After the Iberians, the budget threatened to become a vehicle for massive international income redistribution. While the budget cap had many effects, an important one was to rule out the possibility that structural spending would dictate national contributions in the same way that CAP spending had in the 1970s and 1980s.

The final illuminating aspect of the Iberian enlargement is the Cohesion Fund. This was a new channel for structural spending explicitly separated from the usual Objectives approach. At the Edinburgh summit in December 1992, EU leaders created the Cohesion Fund and crafted the eligibility criteria to ensure that only the poor-4 qualified. Some observers (e.g., Allen, 1996) claim that the poor-4 used their veto power over the Maastricht Treaty as a lever to get the Cohesion Fund (although the former preceded the latter by a year). A rosier interpretation is that the rich EU countries thought that the Cohesion Fund was necessary to help the poor-4 adjust to the changes embodied in economic and monetary union.

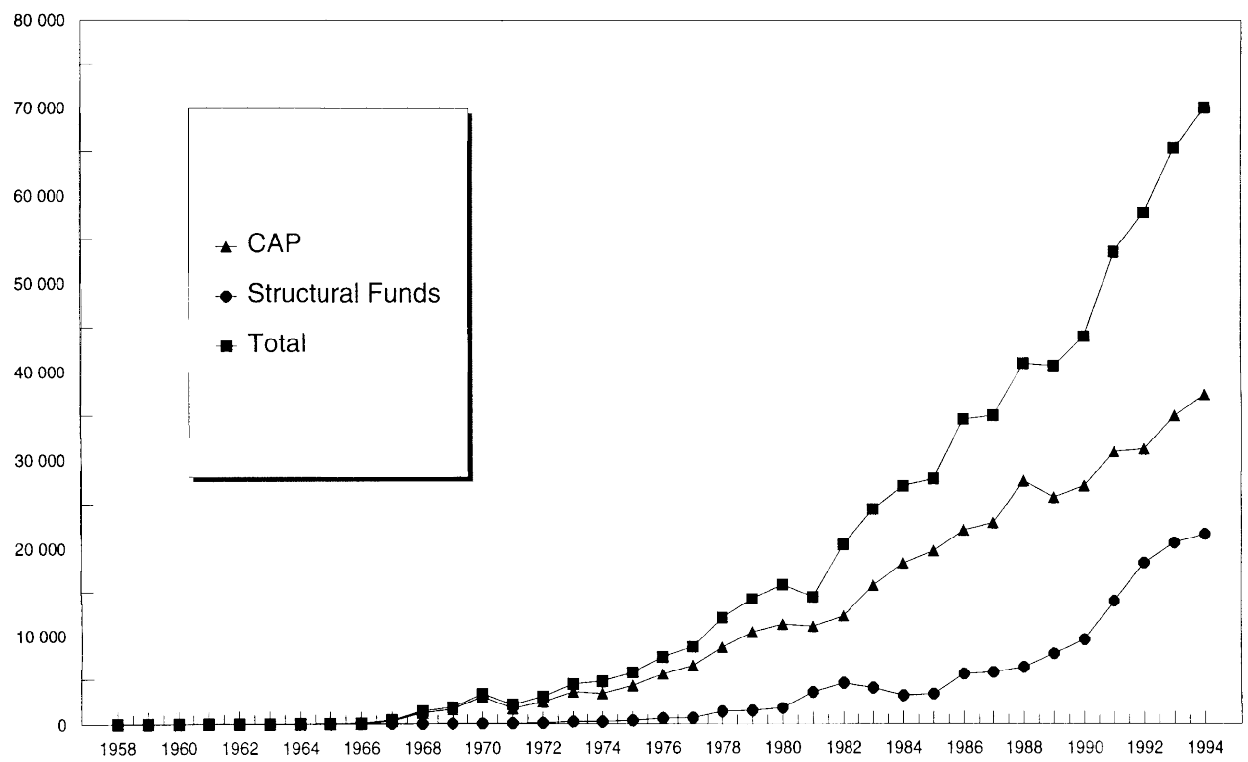

Figure 9. EU spending, 1958-94 (EGUm)

Source: EC (1994a). 
Whichever interpretation is correct, creation of the Cohesion Fund provides further evidence that we cannot take pre-enlargement spending rules as indicative of future spending. New entrants can and have used their power as members to boost EU structural spending in their nations by changing the level of spending and by changing eligibility criteria. Why should the GEECs be any different?

Shifting CAP coverage. CAP price floors are not applied to all EU farm products. Wheat prices, for instance, have always been controlled, while poultry prices have never been. The last ten years, however, have seen the CAP extended to many new products, especially to fruit and vegetables. What explains the extension of CAP coverage? Imagine the EU9 farm ministers sitting around a table in 1980, trying to decide which types of food 'deserve' price support. Since German, French, British, Irish, Belgian, Dutch and Danish farmers all focus on temperate products (e.g., dairy, meat and cereals), the EU9 decided to spend the CAP's billions on temperate products. Fruit and vegetable farmers in Italy and southern France did not, apparently, need price floors. Now imagine the same decision taken by the EU12 farm ministers in 1990. Recalling that fruit and vegetables are the mainstay of Greek, Portuguese and Spanish farms, it is not surprising that the EU12 farm ministers concluded that fruit and vegetable farmers did deserve CAP funds after all. The price of tomatoes, however, can hardly be cast as a matter of vital national interest in the manner of, say, the UK rebate. Consequently, one would not expect the new entrants to make a big issue of it.

Instead, the new entrants gradually used their voting power to reorient CAP spending priorities. Figure 10 shows the results. It plots the growth of CAP spending for the EU12, Greece, Spain and Portugal from 1988 to 1994 (the most recent year available). CAP spending for the EU as a whole rose by $40 \%$ during this period. Portugal managed to increase CAP spending on Portuguese farmers by about $340 \%$. Note that the 1994 level of Portugal's receipts per farmer is still low ECU1500 versus ECU5600 for the average EU12 farmer. Spain and Greece managed similar albeit less spectacular above-average increases. Interestingly, Ireland's CAP receipts (not shown) rose at about the EU12 average, possibly reflecting the fact that they had already exploited their political power to its fullest by 1988. The countries with below-average receipts are the Netherlands, France, Germany and Denmark (not shown).

4.3.3. An econometric analysis of voting power and budgets. The political economy approach suggests that governments will use their voting power to affect the net financial contribution to the EU. Member states with lots of power per citizen should get lots of benefits per citizen, and since someone has to pay for this, citizens living in countries with few votes per citizen should be net contributors. The data in Table 12 show that there is indeed a close correlation between power and net receipts. While it is tempting to lump net contributions and net receipts together, 


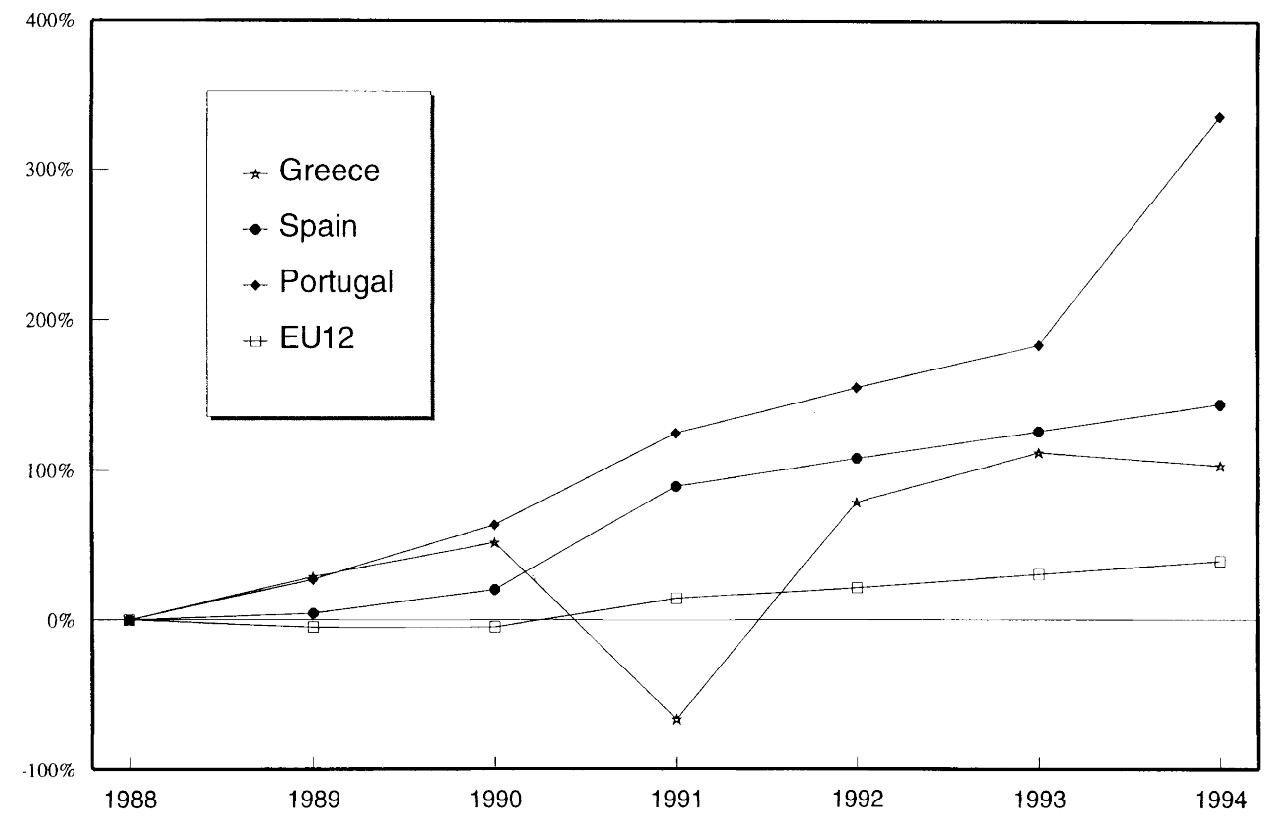

Figure 10. Growth in GAP receipts, 1988-94

Source: EC Commission, The Agricultural Situation in the Community, various issues.

Table 12. Data for 'power politics' model of EU budget

\begin{tabular}{|c|c|c|c|c|c|c|c|}
\hline & \multirow{2}{*}{$\begin{array}{c}\text { GNP/ } \\
\text { population }\end{array}$} & \multirow{2}{*}{$\begin{array}{l}\text { Population } \\
\quad(\mathrm{m})\end{array}$} & \multirow{2}{*}{$\begin{array}{c}\text { Council } \\
\text { votes }\end{array}$} & \multicolumn{2}{|r|}{1994} & \multicolumn{2}{|c|}{1993} \\
\hline & & & & Receipts & Contributions & Receipts & Contributions \\
\hline Belgium & 19640 & 10.0 & 5 & 2512.8 & 2820.2 & 2454.5 & 2451.4 \\
\hline Denmark & 19560 & 5.1 & 3 & 1495.1 & 1307.0 & 1583.4 & 1174.8 \\
\hline Germany & 16850 & 79.1 & 10 & 7729.2 & 21563.3 & 7246.1 & 19006.4 \\
\hline Greece & 9000 & 10.3 & 5 & 4844.2 & 1031.6 & 5147.9 & 877.1 \\
\hline Spain & 13510 & 39.0 & 8 & 7834.7 & 4828.7 & 8263.0 & 5419.4 \\
\hline France & 19000 & 56.2 & 10 & 9924.5 & 12725.5 & 10525.9 & 11884.7 \\
\hline Ireland & 13490 & 3.5 & 3 & 2390.9 & 664.0 & 2939.3 & 554.8 \\
\hline Italy & 17830 & 57.5 & 10 & 5219.2 & 8024.9 & 8739.6 & 11020.1 \\
\hline Luxembourg & 37320 & 0.3 & 2 & 419.1 & 169.3 & 356.6 & 139.8 \\
\hline Netherlands & 17330 & 14.9 & 5 & 2416.0 & 4227.1 & 2704.0 & 4108.0 \\
\hline Portugal & 10710 & 10.0 & 5 & 3042.6 & 1161.7 & 3418.0 & 1067.5 \\
\hline UK & 17210 & 57.2 & 10 & 5258.6 & 6844.0 & 4500.8 & 7685.7 \\
\hline Misc. & & & & 7217.7 & & 6328.6 & \\
\hline Total & & & & 60304.6 & 65367.3 & 64207.7 & 65389.7 \\
\hline
\end{tabular}

Notes: See Court of Auditors p. 10 for Contribution (estimated), p. 54 for actual, p. 17 for unalloc'd Misc. GNP/population and population from World Bank Development Report (1995), table 30 and table 1.

Source: Budget data from EU Court of Auditors, Annual Reports on 1993 and on 1994. 
discussion of the budget and spending procedures suggests that, as we look for measurable links with power, it is preferable to separate out contributions and receipts.

Results of regression analysis are presented in Table 13. The political economy approach suggests that the power of a coalition with a common purpose tends to exceed the sum of the power of the coalition members. This applies well to the poor4 , which have somehow managed to get more cash, as can be seen from the significance of the cohesion variable, a dummy for these four countries (which is interacted with the power variable to measure the slope effect). The two first rows of Table 13 present two specifications for the receipts-per-capita regression, using different measures of power: votes per capita and the SSI index discussed above. The per capita SSI measure of power works best (it gives a higher $R^{2}$ ). Both explanatory variables are significant and of the expected sign. Inspection of the data in Table 12 reveals Luxembourg to be an outlier. To ensure that the results are not driven by a single data point, we show in the third row the regression without Luxembourg. The results reject the idea that Luxembourg is driving our findings. The signs and general orders of magnitude of the estimated coefficients are the same with and without Luxembourg, although the goodness-of-fit statistic $\left(R^{2}\right)$ is slightly lower and the $t$-statistics are much lower, but still above the standard cut-off value.

The discussion above suggests that the rules for national contributions are fairly simple and rigid. While power politics surely influenced these rules, their rigid form allows much less room for the sort of horse trading that the Shapley-Shubik power index brings to mind. The rules on expenditure, however, are massively complex

Table 13. Power politics in the EU budget

\begin{tabular}{|c|c|c|c|c|c|}
\hline & Constant & $\begin{array}{l}\text { Votes per } \\
\text { capita }\end{array}$ & SSI/pop. & Cohesion & $\begin{array}{c}R^{2} \\
\text { No. of observations }\end{array}$ \\
\hline $\begin{array}{l}\text { Receipts per capita } \\
1993-4\end{array}$ & 107.9 & $\begin{array}{c}178.2 \\
(18.8)\end{array}$ & & $\begin{array}{r}511.8 \\
(9.2)\end{array}$ & $\begin{array}{l}0.95 \\
24\end{array}$ \\
\hline $\begin{array}{l}\text { Receipts per capita } \\
1993-4\end{array}$ & 31 & & $\begin{array}{l}375.8 \\
(23.4)\end{array}$ & $\begin{array}{r}259.2 \\
(7.5)\end{array}$ & $\begin{array}{l}0.97 \\
24\end{array}$ \\
\hline \multirow{2}{*}{$\begin{array}{l}\text { Receipts per capita } \\
\text { 1993-4 } \\
\text { w/o Luxembourg }\end{array}$} & 43.5 & & $\begin{array}{r}336.8 \\
(5.7)\end{array}$ & $\begin{array}{r}282.6 \\
(6.1)\end{array}$ & $\begin{array}{l}0.93 \\
22\end{array}$ \\
\hline & Constant & $\begin{array}{l}\text { GDP per } \\
\text { capita }\end{array}$ & & & $\begin{array}{c}R^{2} \\
\text { No. of observations }\end{array}$ \\
\hline $\begin{array}{l}\text { Contribution per capita } \\
1993\end{array}$ & -9.6 & $\begin{array}{l}0.012 \\
(7.8)\end{array}$ & & & $\begin{array}{l}0.86 \\
12\end{array}$ \\
\hline
\end{tabular}

Notes: $t$-statistics in brackets. Cohesion is a slope dummy variable for the poor- $4 \mathrm{EU}$ countries.

Sources: SSI is the Shapley-Subik index of power computed by Kirman and Widgrén (1995); votes are from Baldwin (1994); GNP per capita from World Bank Development Report, 1995; receipts and contributions from EU Court of Auditors (1995). 
and continuously changing. To take account of these facts, we examine whether the contributions per citizen can be well explained by a constant and per capita GNP only. The last row of Table 13 shows that the fit is quite good and the income variable is positive and significant. We did explore alternative specifications. For instance, we tried including a cohesion country dummy, but the estimated coefficient turned out insignificant and slightly negative. For completeness we also regressed per capita contributions on the power index based on the SSI. This yields a positive and significant relationship, but we suspect that this arises from a spurious correlation between very powerful countries and very rich countries (e.g., Luxembourg and Denmark). Indeed, the relationship is not robust to the exclusion of Luxembourg.

4.3.4. Budget projections. We next use rows 1 or 2 and 4 to project the budget impact of the Visegrad enlargement (here we include Slovenia with the original Visegrad-4). Before proceeding, however, we note two important caveats. First, our regressions are based on the 1993-4 budget, yet the EU is already committed to a large increase in spending. Specifically, the long-term budget plan agreed at the Edinburgh Council of December 1992 foresees an increase of 37\% in structural spending between 1994 and 1999 (paid for primarily by a rise in the budget from $1.2 \%$ of EU GNP to $1.27 \%$ of GNP). Thus unless there is a radical change in the $\mathrm{EU}$, the CEECs will be able to exercise their voting power on a much larger pie. The Edinburgh deal shows that the estimated coefficient on the cohesion country dummy understates the power of the poor-4. Using this coefficient to project Visegrad receipts therefore underestimates receipts. The second caveat is that the power of the poor country coalition will experience a qualitative change. The poor- 4 will become the poor-9. The combined votes of Greece, Ireland, Portugal, Spain, the Czech Republic, Hungary, Poland, Slovakia and Slovenia will account for over $40 \%$ of the 112 Council votes in the EU20. Thus even a subset of the poor-9 will have a blocking minority. The implications of this must be tempered with the acknowledgement that the new poor- 5 may be divided between boosting CAP spending and boosting structural spending, since they are heavily agricultural as well as poor.

Assuming that the year of entry is 2002, we present budget projections in Table 14. All CEECs are treated as cohesion countries. The first three columns list results obtained with the SSI power measure; the total Visegrad net receipts are equal to about ECU9 billion. The next three columns show the projections using the votebased power measure and provide a much higher estimate of net costs, about ECU18 billion. (Since the contribution projections do not depend upon the power measure, the difference depends entirely on receipts. The fundamental difference lies in the coefficient on the cohesion country dummy. Since the votes-per-capita measure assigns enormous power to small countries, the regression scales down the effect of power and corrects by raising the coefficient on the slope dummy for poor 
Table 14. Budget projections using the power politics view (Visegrad-5 enlargement in 2002)

\begin{tabular}{lccccccc}
\hline \hline & \multicolumn{3}{c}{ Using SSI power measure } & & \multicolumn{2}{c}{ Using vote-based power measure } \\
\cline { 2 - 3 } & $\begin{array}{c}\text { Projected } \\
\text { receipts } \\
\text { (ECUbn) }\end{array}$ & $\begin{array}{c}\text { Projected } \\
\text { contribution } \\
\text { (ECUbn) }\end{array}$ & $\begin{array}{c}\text { Projected } \\
\text { net } \\
\text { (ECUbn) }\end{array}$ & & $\begin{array}{c}\text { Projected } \\
\text { receipts } \\
\text { (ECUbn) }\end{array}$ & $\begin{array}{c}\text { Projected } \\
\text { contribution } \\
\text { (ECUbn) }\end{array}$ & $\begin{array}{c}\text { Projected } \\
\text { net } \\
\text { (ECUbn) }\end{array}$ \\
\hline Czech Republic & 3.1 & 1.4 & 1.7 & & 4.6 & 1.4 & 3.2 \\
Hungary & 3.1 & 1.1 & 2.0 & & 4.6 & 1.1 & 3.5 \\
Poland & 5.8 & 3.2 & 2.5 & & 9.6 & 3.2 & 6.4 \\
Slovak Republic & 2.4 & 0.6 & 1.8 & & 3.3 & 0.6 & 2.8 \\
Slovenia & 1.7 & 0.4 & 1.3 & & 2.3 & 0.4 & 1.9 \\
Visegrad-5 & 16.1 & 6.7 & 9.4 & & 24.4 & 6.7 & 17.7 \\
\hline \hline
\end{tabular}

Note: Enlargement assumed to occur in 2002, with the Visegrad-5 assumed to grow at $5 \%$ per annum between 1993 and 2002.

Sources: Baldwin (1994) for votes, World Bank Development Report, 1995 for GNP/pop., Kirman and Widgrén (1995) for SSI index (EU20); NB per capita SSI times 100.

countries. Thus the total coefficient on power in the votes-based regression is to predict a per capita receipt of ECU690 per 'unit of power'. For the SSI-based measure the total is only ECU635.)

The similarity between these estimates and the consensus estimate in the previous section is striking. In fact, we find it surprising, since we initially thought that the power politics approach would yield much higher numbers. The mechanics behind the programme-based estimates were explained above. Here we provide some intuition for the power politics approach. The model posits a close correlation between votes per citizen and receipts per citizen, with some adjustment for countries that are part of the poor country coalition. Given that EU rules assign votes according to population, Poland and Spain will get the same number of votes, since they each have about 40 million citizens; the Czech Republic and Hungary will get as many as Greece and Portugal (all four have populations of about 10 million); and the Slovak Republic will get one more than Ireland (populations 5.2 and 3.5 million respectively). Slovenia is not much more than half as large as Ireland. Thus the receipts of the new poor- 5 should be slightly higher than those of the old poor-4. The new poor-5, however, will be substantially poorer, so they will pay less in contributions. In 1994 the incumbent poor-4 got ECU17 billion in receipts and paid ECU7.5 billion in contributions. It is easy to see, therefore, that the projected net ECU15 billion for the Visegrad group is sensible - provided, of course, that one believes that power politics dictate the EU receipts.

Finally, although we do not have estimates of the gains from including the Baltic states, it is simple to project the budget impact of admitting all ten CEECs. Of course, each time the list of members is altered, all the SSI power measures shift (including for incumbents). What Table 15 shows is the projected cost using the SSI 
Table 15. Budget projections using power politics view (enlargements to EU25 in 2002)

\begin{tabular}{lccc}
\hline \hline & \multicolumn{3}{c}{ Using SSI power measure } \\
\cline { 2 - 4 } & $\begin{array}{c}\text { Projected } \\
\text { receipts } \\
\text { (ECUbn) }\end{array}$ & $\begin{array}{c}\text { Projected } \\
\text { contribution } \\
\text { (ECUbn) }\end{array}$ & $\begin{array}{c}\text { Projected } \\
\text { net } \\
\text { (ECUbn) }\end{array}$ \\
\hline Czech Republic & 2.74 & 1.38 & -1.4 \\
Hungary & 2.74 & 1.10 & -1.6 \\
Poland & 5.12 & 3.22 & -1.9 \\
Slovak Republic & 2.07 & 0.58 & -1.5 \\
Slovenia & 1.46 & 0.40 & -1.1 \\
Bulgaria & 2.18 & 0.60 & -1.6 \\
Romania & 3.63 & 0.98 & -2.6 \\
$\quad$ Balkan-2 & $\mathbf{5 . 8}$ & $\mathbf{1 . 6}$ & $-\mathbf{4 . 2}$ \\
& & & \\
Estonia & 1.00 & 0.20 & -0.8 \\
Latvia & 1.48 & 0.22 & -1.3 \\
Lithuania & 1.51 & 0.18 & -1.3 \\
$\quad$ Baltic-3 & $\mathbf{4 . 0}$ & $\mathbf{0 . 6}$ & $\mathbf{- 3 . 4}$ \\
$\quad$ CEEG7 & $\mathbf{1 9 . 9}$ & $\mathbf{8 . 3}$ & $\mathbf{- 1 1 . 7}$ \\
CEEG10 & $\mathbf{2 3 . 9}$ & $\mathbf{8 . 9}$ & $\mathbf{- 1 5 . 1}$ \\
\hline \hline
\end{tabular}

Source: Authors' calculations.

values calculated for the EU25: that is, the incumbent fifteen plus ten CEECs (these SSI figures are taken from Kirman and Widgrén (1995), who unfortunately do not consider membership for Cyprus and Malta). As the last column of the table shows, the projected budget costs are only ECU3.5 billion for the Baltic republics (less than ECU1 billion for Estonia alone).

\section{SUMMARY AND CONCLUDING REMARKS}

This paper estimates the long-run economic benefits and budgetary costs of eastern enlargement under two scenarios. The first views membership for the CEECs as entailing only the standard elements (single market access and the common external tariff). The second additionally assumes that membership promotes CEEC investment by substantially lowering their country-risk premia. Under both scenarios, the incumbent EU15 are projected to gain about EGU10 billion in real income. This gain, however, is likely to be very unevenly distributed. Using a backof-the-envelope procedure, we estimate that Germany, France and the UK would together get about two-thirds of the total gain (Germany alone accounts for about a third of the total gain).

The budget costs are calculated using two very different approaches. The first is based on a survey of the literature estimating likely CAP and cohesion receipts, and 
a rough guess at the CEECs' contributions to the EU budget. We arrive at a consensus estimate of a net cost of ECU23 billion for a Visegrad enlargement in 2000. The second approach is exclusively based on power politics (members' receipts are related to their voting power in the Council of Ministers and per capita national contributions are related to per capita income) and arrives at an estimate of ECU10-18 billion, remarkably, and unexpectedly, similar to the first figure.

\subsection{It's a bargain}

Eastern enlargement will be a phenomenally good bargain for the incumbent EU15. Sweeping aside questions about the timing of the benefits and budget costs, and the list of countries in the first enlargement, the net costs - transfers less benefits should be somewhere between zero and ECU8 billion. Even the upper bound of this range is something like $0.01 \%$ of the EU15's GDP. This is an extraordinarily low cost given the historic nature of the challenge in central Europe. Imagine how eager western Europe would have been in 1980 to pay ECU8 billion a year in order to free central Europe from communism and remove Soviet troops from the region.

Eastern enlargement is not really about transfers and narrowly defined economic benefits. Eastern enlargement is an essential pillar in Europe's post-Cold War architecture. Moreover, imagine that we had done the same economic cost versus budget transfers calculation for Luxembourg and Denmark. Given the massive per capita subsidies they receive and the small size of their economies, we would almost certainly have found that the EU would gain on narrow economic grounds from expelling Luxembourg and Denmark! Of course, no one would suggest that such a move would benefit the EU, since the Union's primary purpose is to ensure peace and stability in Europe. Economic integration is the means, not the end.

\subsection{Who pays the extra budget costs?}

This grand conclusion is the bottom line of our paper. Nevertheless, someone will have to pay the budget transfers, if the enlargement is to happen. This brings us from the stratosphere of high politics back down to the nitty-gritty of low politics. Table 16 explores three ways of sharing out the transfers, taking ECU20 billion as a rounded-off estimate of the extra budget costs. The first column assumes that it is spread out according to the incumbent EU15's contribution shares in 1994. The big4 (Germany, France, Italy and the UK), which are by far the largest contributors, kick in about EGU11 billion; Germany alone pays $30 \%$ of the total. The second column exempts the poor-4 (Ireland, Greece, Portugal and Spain) from any increase. The results are broadly similar, with the obvious difference that all the rich-11 pay a little more. The third column uses our rough estimates of member states' share of the economic gains to apportion the ECU15 billion. Again the numbers are not too different. Germany's share rises to $36 \%$ compared to $31 \%$ 
Table 16. Possible distributions of extra budget costs (EGUbn extra contributions to EU budget)

\begin{tabular}{lccc}
\hline \hline & Straight line & $\begin{array}{c}\text { Straight line } \\
\text { without poor-4 } \\
\text { paying extra }\end{array}$ & $\begin{array}{c}\text { Gains } \\
\text { share } \\
\text { pro rata } \\
\text { from Table 6) }\end{array}$ \\
\hline Germany & 6.2 & 7.0 & 6.8 \\
France & 3.7 & 4.1 & 3.9 \\
UK & 2.0 & 2.2 & 2.8 \\
Italy & 2.3 & 2.6 & 1.7 \\
Spain & 1.4 & 0.0 & 1.4 \\
Netherlands & 1.2 & 1.4 & 0.9 \\
Sweden & 0.5 & 0.5 & 0.8 \\
Belgium-Luxembourg & 0.9 & 1.0 & 0.5 \\
Austria & 0.5 & 0.6 & 0.5 \\
Denmark & 0.4 & 0.4 & 0.4 \\
Finland & 0.3 & 0.3 & 0.3 \\
Greece & 0.3 & 0.0 & 0.1 \\
Ireland & 0.2 & 0.0 & 0.1 \\
Portugal & 0.3 & 0.0 & -0.1 \\
EU15 & & & 20 \\
\hline \hline
\end{tabular}

Note: 1994 contributions for Austria, Sweden and Finland calculated with contributions/population regression from Table 14.

Source: Authors' calculations (see text for methodology).

under the straight-line rule; French and UK shares also rise substantially. Importantly, Portugal gets a rebate and Greece pays virtually nothing. Under the pro rata scheme, Italy pays ECU1 billion less than it does under the straight-line scheme.

\subsection{Gains to the CEECs}

Our estimates project that EU membership will be enormously beneficial to the CEEC economies. Even without considering transfers, and even limiting ourselves to the conservative scenarios, membership will raise CEEC real incomes by 1992 ECU2.5 billion. Our less conservative estimate, which presumes that membership will have an important impact on the CEEGs' country risk, projects very large gains of 1992 ECU30 billion. Adding in farm and Structural Funds transfers, the figure rises to about EGU23 billion for the conservative estimate and EGU50 billion for the less conservative estimates. Of course, our simulation model projects long-run gains, so these extra billions would not be added to GEEG real incomes immediately.

The importance of EU membership to the CEECs, however, is greatly understated by these calculations. A good deal of the progress in the central European transitions has been driven by the prospect of an early eastern enlargement. For instance, the need to meet the Copenhagen membership criteria and adopt the EU's acquis has helped all central European governments to resist special 
interest calls for bad policy. Thus one should probably assign to the prospect of EU membership a good deal of the recent growth experienced in the region. Although the example involves a chicken-and-egg problem, it is worth noting that the CEECs that are keenest on early EU membership are the ones that have pushed forward their transitions the fastest. Delaying accession negotiations could have very negative effects on the CEEC economies and societies.

\section{Discussion}

\section{Dani Rodrik}

Kennedy School of Government, Harvard University

This is an interesting paper, admirable in its attempt to quantify what many policymakers would consider unquantifiable. Its bottom line is that extending membership in the EU to the central and eastern European countries in transition (CEECs) would be a bargain for the EU, and a great boon for the GEECs themselves. I have little to say regarding the discussion of the budgetary implications of enlargement, as I am not familiar with the intricacies of the EU budget. My sense, however, is that the authors exaggerate the economic benefits of enlargement - wildly so in the case of the GEECs - and ignore some of its costs.

\section{Welfare effects of the decline in risk premium}

I think the authors are right in saying that the main economic advantage of EU membership is a potential improvement in the investment climate of the CEECs. They model this effect as a decline in the risk premium faced by these countries, which is also plausible. But their bottom line greatly overstates the economic benefits to the CEECs, even if we accept their assumption of a sizeable decline in the risk premium. The authors calculate that, under their assumption of a $30 \%$ reduction in the required rate of return to capital in the GEECs, due to a fall in the risk premium subsequent to EU entry, the real income of the seven CEEGs will rise by ECU30 billion (or 18.8\%). This is indeed enormous by the standards of computable general equilibrium models. Nowhere do the authors mention, however, that this is a number that has very little economic meaning. This $18.8 \%$ represents the increment in real income in the steady state, largely due to an expanded capital stock. The figure does not take into account the opportunity cost of the investments that had to be undertaken in the transition to the steady state in order to enlarge the capital stock. A simple analogy will help clarify the situation. Suppose Poland were to invest 99\% of its income for the next ten years. At the end of the ten-year period, Poland would have a capital stock that is much larger than it would have been otherwise, and consequently its real income from that point on would be greatly enhanced. 
Should we then recommend that Poland follow this strategy and squeeze its consumption down to $1 \%$ of its income for the next ten years? Of course not. The eventual gains have to be traded off against the consumption losses incurred in the transition. What we need to calculate, therefore, is the welfare benefits of the reduction in the risk premium - that is, the increase in present and future consumption possibilities generated by the reduction in the risk premium - rather than the income gains in the very long run.

There is a simple way of doing this, shown in Figure 11. Let the downwardsloping $V M P K$ schedule represent the demand for the domestic capital stock in the CEECs. Let $r^{*}$ represent the opportunity cost of capital, which we can assume to be the risk-free rate. (There are some complications here, but they are secondary for my purposes.) Let $r$ stand for the risk premium for the CEECs. Following EU entry, the risk premium falls from $r$ to $r^{\prime}$, and the capital stock increases (in the long run) from $K_{0}$ to $K_{1}$. The welfare gain here is the sum of the areas $A$ and $B$, which can be expressed as $D W=1 / 2\left(r+r^{\prime}\right)\left(K_{1}-K_{0}\right)$. Expressing this quantity in terms of national income $(Y), \quad D W / Y=1 / 2\left(r+r^{\prime}\right)\left[\left(K_{1}-K_{0}\right) / K_{0}\right]\left(K_{0} / Y\right)$. Hence we need three numbers to approximate the true welfare effect of the reduction in the risk premium: the average of the pre- and post-risk premia for CEECs, the percentage increase in the capital stock, and the capital-output ratio. The first of these numbers is no larger than 0.04 (it is hard to be completely clear from the discussion in the paper). For the second, I take the authors' result of $68 \%$ (leaving aside the question of whether the implied elasticity for capital is not too large). For the capital-output ratio, I substitute the Singapore figure for 1970 (1.4), which is likely to be an overestimate. Even with these generous assumptions, the result is an increase in welfare of $3.8 \%$, which is only a fraction of the $18.8 \%$ figure presented in the paper.

Figure 11 also clarifies the nature of the exercise carried out by the authors, and why it is misleading. The increase in national income in the long run is simply the

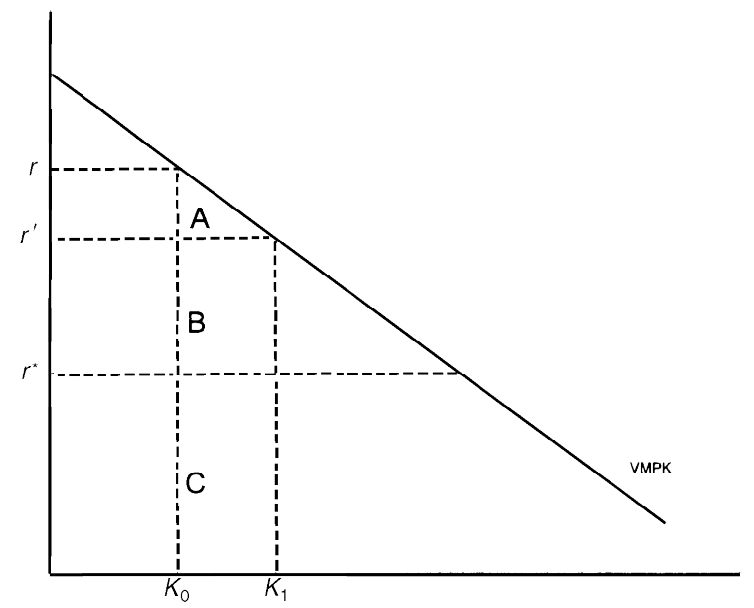

Figure 11. The welfare effect of the reduction in the risk premium 
increment in national output due to the enlarged capital stock. This can be calculated as $D Y / Y=\left(r^{*}+r\right)\left[\left(K_{1}-K_{0}\right) / Y\right]=\left[\left(r^{*}+r\right) K_{0} / Y\right] \quad\left[\left(K_{1}-K_{0}\right) / K_{0}\right]=$ $a\left[\left(K_{1}-K_{0}\right) / K_{0}\right]$, where $a$ denotes the factor share of capital in national income. Assuming $a$ is 0.30 , we get $D Y / Y=(0.3)(0.68)=20.4 \%$, which is close to the authors' $18.8 \%$. But note that this represents the sum of areas $A, B$ and $C$ in Figure 11. It does not have a meaningful economic interpretation as a guide to policy choice unless we are prepared to assume that the opportunity cost of capital $\left(r^{*}\right)$ is near zero! Even leaving this point aside, there is the issue of discounting. The calculated gains are those that accrue in the steady state, which is in fact never reached. The figures need to be expressed in present-discounted value terms, which requires that these gains be calculated for some suitable neighbourhood of the steady state and then discounted back to the present.

\section{Further issues related to CEECs}

I said above that the main economic advantage of EU membership is a potential improvement in the investment climate of the CEECs. The authors downplay any doubts about this potential being fulfilled, including their own rather inconclusive before-and-after comparisons. There are two questions here: (1) Is it reasonable to expect the risk premium to fall in all of the CEECs, and if so, to fall by the full amount that the authors have assumed? (2) If the answer to (1) is yes, is it reasonable to expect the capital stock to rise by as much as $68 \%$ ? On the first question, I would have liked to see the authors think harder about what makes some countries (e.g., Portugal?) take full advantage of the opportunities presented by EU membership, while others (Greece?) use the opportunity to engage in patronage politics. The evidence is that the improvement in the investment climate does not come automatically; it is contingent on the choices made by domestic political authorities. The availability of additional resources from Brussels, in particular, can have deleterious effects on governance (as it seems to have had in Greece, for example). On the second question, one would have liked to see some numbers on what the simulations imply for things like the share of foreign ownership in the domestic economy, profit remittances as a share of GNP, the long-run trade balance, and the long-run debt- and capital-output ratios. These would give us a sense of whether the implied path is a sensible one, consistent with cross-country evidence.

\section{Political and bureaucratic costs of enlargement for the EU}

The authors probably underestimate these costs. With a substantial expansion of membership, the EU bureaucratic machinery is likely to become even more unwieldy. (Think, for example, of the added cost of preparing translations of all EU documents in seven new languages.) Reaching decisions on a unanimous or qualified-majority basis is likely to become more difficult. Furthermore, the greater 
diversity of needs and preferences within the EU is likely to make the single market and EMU more problematic throughout. Political and bureaucratic gridlock in an enlarged EU is a real danger that should be taken seriously.

To sum up, the paper greatly exaggerates the real economic benefits that will accrue to CEECs from EU membership, even under the paper's own assumptions about likely future scenarios. Furthermore, these gains are contingent on 'correct' policies being followed by the new members, which is something that cannot be taken for granted, especially since we do not always know what these 'correct' policies are. Finally, the bureaucratic/political costs of enlargement are likely to be larger than the authors indicate. For all these reasons, the paper has not moved much my priors about the desirability of EU enlargement.

\section{István P. Székely}

\section{National Bank of Hungary and Budapest University of Economics}

This is an excellent paper which applies a wide variety of methods to come to sensible estimates. What is really surprising is that different methods lead to remarkably similar conclusions. It is also remarkable how little attention is paid to the costs and benefits of enlargement within CEEGs, and a telling fact that the authors could not find estimates to refer to. Hopefully, this paper will help politicians and economic policy-makers in the GEEGs to understand the importance of this issue.

As the authors themselves point out, 'enlargement is not only about transfers and narrowly defined economic benefits. Eastern enlargement is an essential pillar in Europe's post-Gold War architecture.' That is, the decisions about enlargement will probably be political. Yet, economic issues will be very much part of the picture. Economic costs and benefits will bear on decisions, particularly on the details. As we know, the devil lives in the detail. According to this paper, an overwhelming proportion of the benefits for the GEECs come from two sources: own-liberalization of trade and generally sound policies which reduce the country risk premium. In principle, both types of policy could be achieved without EU membership. However, the authors note that the desire for, and realistic chances of, EU membership serve as powerful commitment and prevention devices as they limit the power of lobbies with conflicting entrenched interests. The prospect of membership increases the likelihood and credibility of sound macroeconomic policies and structural reforms. Once more, the political economy turns out to be crucially important.

What is missing in the debate is the alternative: no enlargement and its own costs. Yet no enlargement at all does not seem a realistic option. More relevant is how to define the right group for the first wave of entrants, and how to time this first wave. The paper struggles with the first issue, but does not say anything about the second. This is not surprising, since the authors' approach is geared towards the long run. 
Yet, they end up somewhat unclear about which countries they regard as adequate first-wave entrants. Sometimes they seem to favour the Visegrad-4, at other times it is the Visegrad-5 (that is, adding Slovenia to the Czech and Slovak Republics, Hungary and Poland), while occasionally Estonia appears as the front-runner. And yet they never attempt to link their list to the costs and benefits that they provide. Could it be that political considerations are completely overwhelming in the choice of timing?

In the event that the (political) decision of enlargement (selection of countries, timing, conditions, etc.) is perceived by the financial markets as economically unsound, the EU15 might pay a penalty in the form of a risk premium. This issue is overlooked in the paper. Of course, the premium would be much smaller than the current one affecting the CEECs. Yet, given the size of the EU15 economies, the economic effect could be large.

\section{General discussion}

Patrick Rey felt that the analysis, while claiming to be about the costs and benefits of eastern enlargement, had focused primarily on the benefits. Though the authors have found the net cost of enlargement to be quite small, it is noteworthy that this emerged as the difference of two magnitudes that were themselves quite small. $\mathrm{He}$ urged them to do more work on the cost side of the analysis. Likewise, André Sapir was not persuaded that the cost of enlargement is small. While the estimated net cost - about EGU15 billion - seems small in relation to the total GDP of the EU (about ECU6000 billion), it represents a significant chunk of the EU budget of about ECU60 billion. Where would the required funds come from, given that the current EU members lack the political will to increase their contribution by an average of $0.25 \%$ of their GDP? Such a significant amount cannot be simply released by a reallocation of the existing budget. Furthermore, contributions are hard to measure. For instance, the Netherlands' net contribution to the EU is hard to measure because of the so-called Rotterdam effect: as a major port of entry, Rotterdam collects a considerable amount of tariff revenue on goods entering the EU.

Barry Eichengreen felt that the paper misses some important elements of the relationship between the EU and eastern Europe, both now and after enlargement. First, foreign direct investment, unlike portfolio investment, tends to concentrate on particular sectors and particular countries. In particular, $60 \%$ of the FDI to eastern Europe has gone to just one country, Hungary. Second, the simulations do not take into account the fact that a lot of the exports from eastern Europe to the EU are in the low-wage, low-value-added category. For instance, $70 \%$ of the Romanian exports to the EU are of the kind where they import sleeves and collars and export shirts. This is significant because such production activity contributes little in the way of learning effects and productivity improvements, and the spillover effects that 
one hopes for are often missing. Third, the analysis neglects the implications of enlargement for the issue of labour mobility.

Willem Buiter concurred that labour mobility is an important issue. Given the wage and human capital differentials between the east and the west, one would expect massive migration flows. He also took issue with the hope that enlargement will lead to the liberalization of goods markets in eastern Europe. In a number of sectors, especially agriculture, accession to the EU will probably lead to the deliberalization of markets. Finally, he advocated caution in the use of country risk indices when considering risk premia for investment. Country risk measures are single country measures and, as such, not entirely appropriate to the risk-return relationship, say, in the capital asset pricing model.

Vidar Christiansen called for more discussion of the political economy aspects of enlargement. In particular, when discussing the role of new members in the decision-making process, it is important to distinguish between their pre-entry and post-entry positions. For instance, while some Nordic members of the EU were persuaded to join by the carrot of financial support for their remote regions, such incentives are probably unnecessary for eastern European countries. For Bruno Frey, the essential question was: how will integration affect the huge, and largely unproductive, public sector in these countries? Clearly, the simulation is unable to capture questions of this sort. He conjectured that integration would be beneficial to both the east and the west if it induced more political competition within these countries.

In response to the comments, Richard Baldwin argued that CGE models are typically unable to capture FDI, except through trade. Responding to Willem Buiter's point of the danger of increased protection, he argued that eastern Europe is more protected than the EU except in agriculture. On the issue of labour mobility, Richard Portes felt that there will be a long transition period before full labour mobility is allowed, and by that time the wage differentials will not be so significant.

\section{REFERENCES}

Anderson, K. and R. Tyers (1995). 'Implications of the EC Expansion for European Agriculture Policies, Trade and Welfare', in R. Baldwin, P. Haaparanta and J. Kiander (eds.), Expanding Membership of the European Union, Cambridge University Press, Cambridge.

Allen, D. (1996). 'Cohesion and Structural Adjustment', in H. Wallace and W. Wallace (eds.), Policy-Making in the European Union, Oxford University Press, Oxford.

Bajo, O. and S. Sosvilla (1992). 'Inversion directa extranjera en España', Moneda y Credito, no. 194.

Baldwin, R.E. (1994). Towards an Integrated Europe, CEPR, London.

and J.F. Francois (eds.) (1996). Dynamic Issues in Applied Commercial Policy Analysis, Cambridge University Press, Cambridge.

- and E. Seghezza (1996). 'Trade-Induced Investment-Led Growth', NBER Working Paper No. 5582. - and A. Venables (1995). 'Regional Economic Integration', in K. Rogoff and G. Grossman (eds.), Handbook of International Economics, 3, North-Holland, Amsterdam.

_ D. Begg, J.-P. Danthine, V. Grilli, J. Haaland, M. Neumann, V. Norman, A. Venables and A. Winters (1992). 'Is Bigger Better? The Economics of EC Enlargement', in Monitoring European Integration, CEPR, London.

Begg, I. (1996). 'Inter-Regional Transfers in a Widened Europe', paper presented at Kiel Week Conference. Braga de Macedo, J. and F. Torres (1990). 'Interest Differentials, Integration and EMS Shadowing: A Note on 
Portugal with a Comparison to Spain', in J.S. Lopes and L.M. Beleza (eds.), Portugal and the Internal Market of the EEC, Banco de Portugal, Lisbon.

Brenton, P. and D. Gros (1993). 'The Budgetary Implications of EG Enlargement', CEPS Working Document No. 78, Centre for European Policy Studies, Brussels.

Brown, D., A. Deardorff, S. Djankov and R. Stern (1995). 'An Economic Assessment of the Integration of Czechoslovakia, Hungary and Poland into the EU', AICGS Economic Working Paper No. 8.

Courchene, T., G. Goodhart, A. Majocchi, W. Moesen, T. Prud'homme, F. Schneider, S. Smith, B. Spahn and C. Walsh (1993). 'Stable Money - Sound Finances', European Economy, No. 53, European Commission, DG 2, Brussels.

EG (1994a). 'Vade-Mecum Budgetaire', European Commission, DG 11, Brussels.

(1994b). 'EC Agricultural Policy for the 21st Century', European Economy Reports and Studies, 4, Brussels.

- (1995a). 'Interim Report from the Commission to the European Council on the Effects on the Policies of the European Union of Enlargement to the Associated Countries of Central and Eastern Europe', mimeo., CSC (95) 605, European Commission, Brussels.

(1995b). 'Agricultural Situation and Prospects in the Central and Eastern European Countries: Summary Report', European Commission, DG 6, Brussels.

EC (1995c). 'Study on Alternative Strategies for the Development of Relations in the Field of Agriculture Between the EU and the Associated Countries with a View to Future Accession of these Countries', CSE (95) 607, European Commission, DG 6, Brussels.

El-Agraa, Ali (1994). The Economics of the European Community, Harvester-Wheatsheaf, London.

EU Court of Auditors (1995). Annual Report Concerning the Financial Year 1994.

Faini, R. and R. Portes (1995). 'Opportunities Outweigh Adjustment: The Political Economy of Trade with Central and Eastern Europe', in R. Faini and R. Portes (eds.), EU Trade with Eastern Europe: Adjustment and Opportunities, CEPR, London.

Finger, M., M. Ingco and U. Reincke (1996). The Uruguay Round: Statistics on Tariff Concessions Given and Received, World Bank, Washington, DC.

Francois, J.F. and D.W. Roland-Holst (1996). 'Trade Policy, Scale Economies, and Imperfect Competition in Applied Models', in Francois and Reinert (1996).

Francois, J.F. and K.A. Reinert (eds.) (1996). Applied Methods for Trade Policy Analysis: A Handbook, Cambridge University Press, Cambridge.

Francois, J.F., B. MacDonald and H. Nordström (1995). 'Assessing the Uruguay Round', in W. Martin and A. Winters (eds.), The Uruguay Round and the Developing Economies, World Bank Discussion Paper No. 201.

Grabbe, H. and K. Hughes (1996). 'The Impact of Enlargement on EU Trade and Industrial Policy', in J. Redmond and G. Rosenthal (eds.), Enlargements of the European Union: Past, Present and Future, forthcoming.

Jackson, M. and J. Swinnen (1994). 'A Survey and Evaluation of the Current Situation and Prospects of Agriculture in the Central and Eastern European Countries, with Emphasis on Six States with European Agreements', Final Report to the European Commission, DG 1, Brussels.

Kirman, A. and M.Widgrén (1995). 'Voting in the European Union: European Economic Decision-Making Policy: Progress or Paralysis?', Economic Policy.

Krugman, P.R. (1979). 'Increasing Returns, Monopolistic Competition, and International Trade', Fournal of International Economics.

Laffan, B. and M. Shackleton (1996). 'The Budget', in H. Wallace and W. Wallace (eds.), Policy-Making in the European Union, Oxford University Press, Oxford.

Mahé, L.-P. (1995). 'L'agriculture et l'élargissement de l'Union européenne aux pays d'Europe centrale et orientale: transition en vue de l'intégration ou intégration pour la transition?', Study for DG 1, European Commission, Brussels.

OECD (1992). Agricultural Policies, Markets and Trade, Paris.

Ortega, E., J. Salarenia and J. Viñals (1990). 'Spain's Current and Capital Accounts Balances within the EEC', in Bank for International Settlements, International Capital Flows, Exchange Rate Determination and Persistent Current Account Balances, Basle.

Slater J. and N. Atkinson (1995). 'The Common Agricultural Policy and EU Enlargement to the East', UK Ministry of Agricultural, Fisheries and Food.

Smith, A., P. Holmes, U. Sedelmeier, E. Smith, H. Wallace and A. Young (1995). 'The European Union and Central and Eastern Europe: Pre-Accession Strategies', Sussex European Institute Working Paper No. 15.

Strasser, D. (1992). The Finances of Europe, 7th edn, Office for Official Publications of the European Communities, Luxembourg.

Tangermann, S. (1996). 'Reforming the CAP: A Prerequisite for Eastern Enlargement', paper presented at Kiel Week Conference.

- and T. Josling (1994). 'Pre-Accession Agricultural Policies for Central Europe and the European Union', Study for DG 1, European Commission, Brussels.

Tyers, R. (1994). 'Economic Reform in Europe and the Former Soviet Union: Implications for International Food Markets', Research Report No. 99, International Food Policy Research Institute, Washington, DC.

Viñals, J. et al. (1990). 'Spain and the "EC cum 1992" shock', in C. Bliss and J. Braga de Macedo (eds.), Unity with Diversity in the European Economy, Cambridge University Press, Cambridge.

World Bank (1995). World Development Report, New York. 